\title{
POTENSI VEGETASI SEBAGAI PEREDAM INGAR BUNYI KENDARAAN BERMOTOR
}

\author{
KEMALA
}

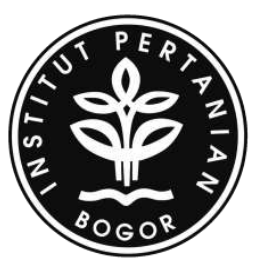

DEPARTEMEN BIOLOGI

AKULTAS MATEMATIKA DAN ILMU PENGETAHUAN ALAM INSTITUT PERTANIAN BOGOR

BOGOR 2013 


\section{HALAMAN PERNYATAAN}

Dengan ini saya menyatakan bahwa skripsi berjudul Potensi Vegetasi sebagai Peredam Ingar Bunyi Kendaraan Bermotor adalah benar karya saya denga arahan dari pembimbing dan belum diajukan dalam bentuk apapun kepada perguruan tinggi manapun. Sumber informasi yang berasal atau dikutip dari karya yang diterbitkan maupun tidak diterbitkan dari penuis lain telah disebutkan dalam teks dan dicantumkan dalam Daftar Pustaka di bagian akhir skripsi ini.

Dengan ini saya melimpahkan hak cipta dari karya tulis saya kepada Institut Pertanian Bogor.

Bogor, September 2013

Kemala

NIM G34080050 


\section{ABSTRAK}

KEMALA. Potensi Vegetasi sebagai Peredam Ingar Bunyi Kendaraan Bermotor. Dibimbing oleh IBNUL QAYYIM dan SOBRI EFFENDY.

Alat transportasi yang jumlahnya semakin bertambah setiap harinya menyebabkan berbagai macam dampak kesehatan terutama pada manusia. Berdasarkan dampak yang ditimbulkan, ada tiga cara yang dapat dilakukan untuk mencegah, mengurangi, atau mengendalikannya. Pertama, kontrol kebisingan pada sumber, kedua, kontrol kebisingan pada lintasan, dan ketiga, kontrol kebisingan pada penerima (manusia). Penelitian ini khusus membahas tentang Kontrol kebisingan pada sumber bising dengan media tanaman. Tujuan dari p̌enelitian ini adalah mengetahui potensi vegetasi sebagai peredam ingar bunyi Rhususnya ingar bunyi yang berasal dari kendaraan bermotor. Pengukuran i⿱⺈tetensitas kebisingan dilakukan dengan Sound Level Meter yang berlokasi di jalan Hetro Pondok Indah dan dilakukan di dua titik pengamatan, daerah kontrol tanpa 츨etasi dan daerah perlakuan dengan vegetasi. Pengukuran dilakukan pada hari kerja dan hari libur, dengan waktu pengukuran dilakukan pada pagi, siang, dan sore hari. Pengukuran dilakukan dengan tiga kali ulangan. Hasil pengamatan menunjukkan bahwa intensitas kebisingan pada daerah kontrol berkisar antara Z7 3-79.4 dBA, sedangkan pada daerah perlakuan intensitas bising berkisar antara 56.3-59.4 dBA. Dalam hal ini vegetasi memang mampu meredam ingar sebanyak 20-21 dBA bunyi walaupun kedua hasil tersebut telah melebihi baku mutu kebisingan yang telah ditetapkan oleh KemenLH no. 48/1996, yaitu 65 dBA untuk kawasan perkantoran dan perdagangan (daerah kontrol) dan 55 dBA untuk daerah perumahan dan pemukiman (daerah perlakuan).

Kata kunci: ingar bunyi, kebisingan lalulintas, peredaman bising, vegetasi

$\sqrt{3}$

\section{ABSTRACT}

KEMALA. The Potentional of Vegetation as Attenuator of Traffic Noise. Guidanced by IBNUL QAYYIM and SOBRI EFFENDY.

The increases of transportation everyday have made multiple effects especially for human health. Based on the effects appeared by noise, there were three steps could be done to prevent, to reduce, or to control it. First, noise control at the source of noise, second, noise control at the line, and third, noise control for the receiver (human). This research focus on noise control at the source of noise by plants. The purpose of this research was to investigate the traffic noise attenuation (by vegetation. The noise was measured with Sound Level Meter and was taken at two areas, control area without vegetation and deal area with vegetation. Measurement was done in busy days and weekday in the morning, midday, and afternoon. The measurement repeated as many as three. The observation showed that the traffic noise in control area ranging from 77.3-79.4 dBA, whereas in deal area traffic noise ranging from 56.3-59.4 dBA. In this case, vegetation could reduce the traffic noise as many as 20-21 dBA although the observation result ever quality standard which defined by The Ministry of Environmentno. 48/1996, that was $65 \mathrm{dBA}$ for office and commerce (control area), and $55 \mathrm{dBA}$ for housing and settlement (deal area).

Key words: noise, traffic noise, noise reduction, vegetation 


\section{CHak Cipta Milik IPB, Tahun 2013}

\section{Hak Cipta Dilindungi Undang-Undang}

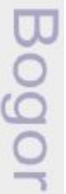

Ditarang menguti sebagian atau seluruh karya tulis ini tanpa mencantumkan atow menyebutkan sumbernya. Pengutipan hanya untuk kepentingan pendidikan, penelitian, penulisan karya ilmiah, penyusunan laporan, penulisan kritik, atau tinjauan suatu masalah; dan pengutipan tersebut tidak merugikan kepentingan IPB.

Ditarang mengumumkan dan memperbanyak sebagian atau seluruh karya tulis ini=dalam bentuk apapun tanpa izin IPB. 


\title{
POTENSI VEGETASI SEBAGAI PEREDAM INGAR BUNYI KENDARAAN BERMOTOR
}

\author{
KEMALA \\ Skripsi \\ sebagai salah satu syarat untuk memperoleh gelar \\ Sarjana Sains \\ pada \\ Departemen Biologi
}

\author{
DEPARTEMEN BIOLOGI \\ AKULTAS MATEMATIKA DAN ILMU PENGETAHUAN ALAM \\ INSTITUT PERTANIAN BOGOR \\ BOGOR \\ 2013
}




\section{LEMBAR PENGESAHAN}

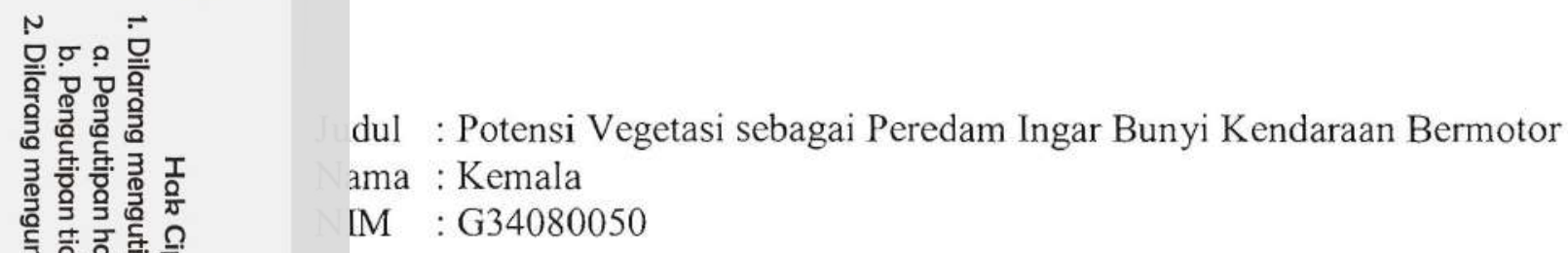

(C)

Disetujui oleh
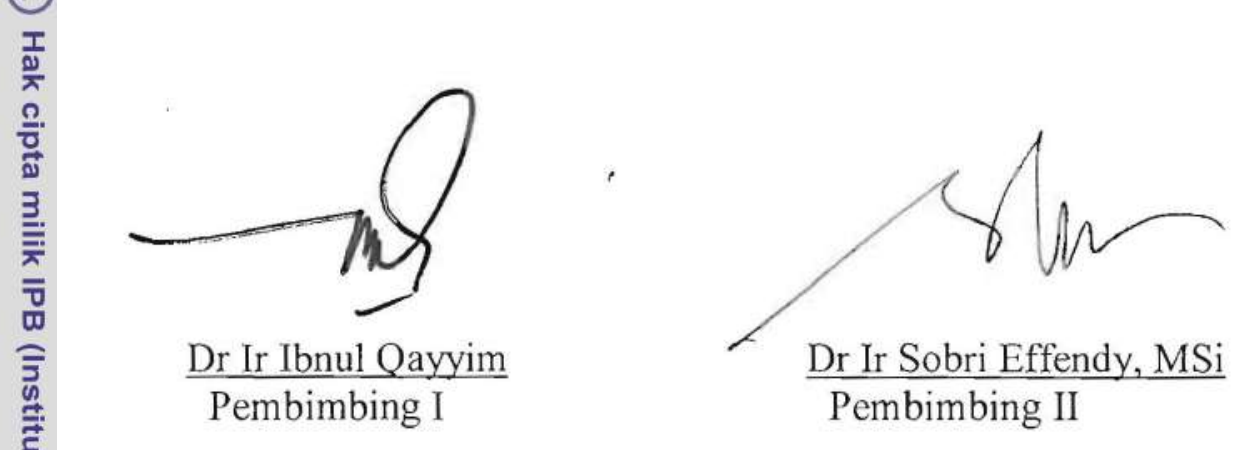

Diketahui oleh

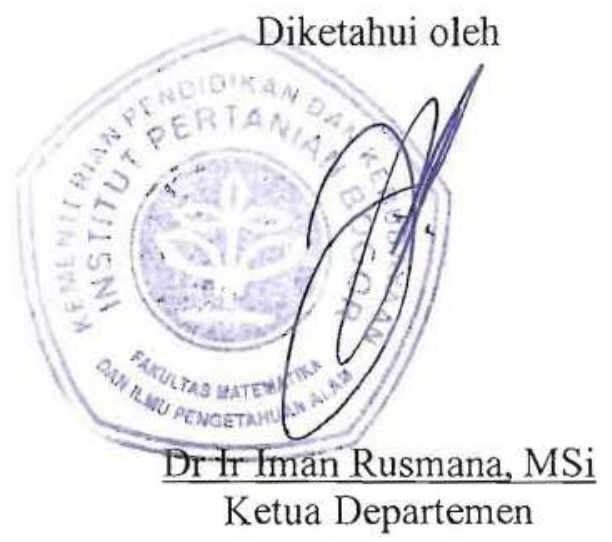

ए 


\section{LEMBAR PENGESAHAN}

등 Judul : Potensi Vegetasi sebagai Peredam Ingar Bunyi Kendaraan Bermotor Nama : Kemala

\section{엘 : G34080050}

Disetujui oleh

Dr Ir Ibnul Qayyim

Pembimbing I
Dr Ir Sobri Effendy, MSi

Pembimbing II

Diketahui oleh

Dr Ir Iman Rusmana, MSi

Ketua Departemen 


\section{KATA PENGANTAR}

Puji syukur penulis panjatkan kepada Allah SWT yang telah memberikan rahmat dan hidayah-Nya sehingga karya ilmiah ini dapat terselesaikan dengan baik. Karya ilmiah ini diberi judul Potensi Vegetasi sebagai Peredam Ingar Bunyi Kendaraan Bermotor, yang dilakukan dari bulan Februari 2012 hingga Oktober 2012 yang bertempat di jalan Metro Pondok Indah Jakarta Selatan dan Laboratorium Anatomi Tumbuhan, Departemen Biologi, IPB.

Penulis mengucapkan terima kasih kepada Bapak Dr Ir Ibnul Qayyim selaku pembimbing I dan Bapak Dr Ir Sobri Effendy, MSi selaku pembimbing II yang telah membimbing, memberi arahan, serta koreksi selama penelitian dan penulisan karya ilmiah ini. Ucapan terima kasih juga penulis sampaikan kepada Zuhay, Puspa, Uun, Andri, Pak Parman, dan kepada teman-teman di lab Anatomi Tumbuhan, serta teman-teman Biologi 45, yang telah menjadi teman diskusi dan terima kasih atas perhatian yang diberikan. Terakhir, terima kasih juga penulis sampaikan kepada seluruh keluarga besar atas do'a dan dukungannya selama ini. Semoga hasil penelitian ini bermanfaat sebagai informasi dalam dunia pendidikan. Kritik serta saran penulis harapkan sebagai bahan koreksi dan perbaikan untuk penelitian selanjutnya.

Bogor, September 2013

Kemala 


\section{DAFTAR ISI}

DAFTARGAMBAR vii

DAFTAR LAMPIRAN

PENDAHULUAN

Latar Belakang

Tujuan

BAHAN DAN METODE

Waktu dan Tempat

Bahan

Metode

Pengamatan Pendahuluan

Penghitungan Kendaraan Bermotor

Pengukuran Suhu

Pengukuran Intensitas Kebisingan

Pengamatan Vegetasi

Pengamatan Mikroskopis

Analisis Data

1

1

2

2

2

2

2

2

3

3

4

4

5

5

HASIE

Renghitungan Kendaraan Bermotor

6

Bengukuran Suhu

7

Pengukuran Intensitas Kebisingan $\quad 8$

Pengamatan Vegetasi 9

Pengamatan Mikroskopis $\quad 11$

PEMBAHASAN

13

SIMPULAN DAN SARAN 15

DAFTAR PUSTAKA 16

$\begin{array}{ll}\text { LAMPIRAN } & 17\end{array}$ 


\section{DAFTAR GAMBAR}

$\begin{array}{ll}\text { Jumlah masing-masing kategori kendaraan pada hari pengamatan } & 7\end{array}$

Suhu udara $\left({ }^{\circ} \mathrm{C}\right)$ di daerah kontrol pada tiga waktu pengamatan $\quad 8$

Suhu udara $\left({ }^{\circ} \mathrm{C}\right)$ di daerah perlakuan pada tiga waktu pengamatan $\quad 8$ Intensitas bising (dBA) di daerah kontrol dan daerah perlakuan dalam tiga waktu pengukuran

Pengurangan intensitas bising oleh vegetasi 10

Vegetasi yang ada di lokasi $\quad 11$

$\begin{array}{ll}\text { Sayatan transversal adaksial } & 12\end{array}$

Sayatan transversal abaksial $\quad 12$

Sayatan transversal trikoma pada Bambu 13

Sayatan transversal hipodermis pada Cempaka 13

\section{DAFTAR LAMPIRAN}

Lokasi pengamatan $\quad 18$

Jumlah kendaraan kendaraan pada tiga waktu pengamatan 19

Suhu $\left({ }^{\circ} \mathrm{C}\right)$ di daerah kontrol dan daerah perlakuan 19

Intensitas kebisingan (dBA) di daerah kontrol dan daerah perlakuan 20

Intensitas bising (dBA) di daerah kontrol dan daerah perlakuan pada jarak

$61 \mathrm{~m}$ dan pengurangannya oleh vegetasi

Ukuran karakteristik fisiognomi tumbuhan tegak yang berada di lokasi

pengamatan

Tebal kutikula (adaksial dan abaksial) dan epidermis (adaksial dan abaksial) 



\section{PENDAHULUAN}

\section{Latar Belakang}

Jumlah alat transportasi yang semakin meningkat tiap harinya menyebabkan berbagai dampak. Bunyi yang dihasilkan oleh mesin kendaraan bermotor menyebabkan polusi suara atau ingar bunyi. Ingar bunyi adalah bunyi yang tidak diinginkan, yang akan mengganggu pendengarnya. Erdogan dan Yazgan (2009) mendefinisikan bunyi sebagai proses fisik yang terjadi sebagai hasil fluktuasi oleh sumber getaran dalam tekanan udara dan menstimulus indera pendengaran manusia, sedangkan ingar bunyi adalah bunyi dengan struktur yang tidak teratur.

Sumber ingar bunyi dapat dibagi dua: sumber yang berasal dari dalam gedung dan sumber yang berasal dari luar gedung. Sumber ingar bunyi yang Eerasal dari dalam gedung meliputi bunyi hasil dari pembicaraan, langkah kaki, serta peralatan rumah tangga, sedangkan sumber yang berasal dari luar gedung dapat berasal dari alat transportasi, industri, konstruksi, dan hewan. Sumber bunyi te rutama ada karena hasil dari kegiatan manusia.

Tingkat ketergangguan yang dialami masing-masing orang berbeda tergantung tinggi tingkatan bunyi yang didengar dan frekuensi terpapar oleh bunyi bising, sehingga ingar bunyi merupakan suatu penilaian subjektif dari tiap îdividu manusia. Ingar bunyi dapat mengakibatkan beberapa dampak pada manusia yang tidak ringan. World Health Organization (WHO) (2012) membuat empat klasifikasi dampak ingar bunyi terhadap kesehatan manusia, yaitu dampak fisis, dampak fisiologi, dampak psikologi, dan dampak daya kerja.

$\cong \quad$ Dampak fisik meliputi kehilangan pendengaran sementara dan permanen. Dampak fisiologi meliputi kesulitan bernapas, ketidakteraturan detak jantung, peningkatan tekanan darah, ketidakteraturan gula darah, gangguan tidur, dan asma. Dampak psikologi meliputi sulit berkonsentrasi, perasaan marah, kekecewaan, kegelisahan, dan depresi. Dalam dampak daya kerja meliputi menurunnya kemampuan dalam membaca, belajar, dan bekerja, serta kurang konsentrasi. Menurut Chaeran (2008), dampak kebisingan terhadap kesehatan tubuh karyawan yang bekerja di bandara beragam, seperti kurang pendengaran, sering mengalami susah tidur, tidak bisa tidur, dan tidak merasakan gangguan akibat bising.

Berdasarkan dampak yang ditimbulkan, ada tiga langkah yang dapat dilakukan untuk mencegah, mengurangi, ataupun untuk mengendalikan bunyi bising. Pertama, kontrol kebisingan pada sumber kebisingan, kedua, kontrol CRebisingan pada lintasan, ketiga, kontrol kebisingan pada penerima (manusia). Kontrol yang pertama dapat dilakukan dengan membuat dinding pembatas yang terbuat dari material keras (seperti tembok) maupun dapat dilakukan dengan (Penanaman tumbuhan beberapa lapis yang memiliki tutupan tajuk yang lebat dan berdaun lebar. Kontrol kedua dapat dilakukan dengan modifikasi pada bahan Tintasan kendaraan dan roda pada kendaraan. Kontrol ketiga dapat dilakukan dengan penggunaan penyumbat telinga (earplug), penutup telinga (earmuff), dan helm. Penggunaan earplug dapat mengurangi sekitar 20-40 dBA; earmuff dapat mengurangi 35-40 dBA; dan helm dapat mengurangi sekitar 10-30 dBA (Berger \& Casali 1998). Menurut Yang et al. (2011), tujuan utama dari pengendalian ingar 
bunyi adalah untuk meningkatkan kenyamanan, kepuasan, dan kesejahteraan penduduk kota. Penelitian ini khusus membahas mengenai potensi tumbuhan sebagai peredam kebisingan.

\section{Tujuan}

Penelitian ini bertujuan mengetahui potensi vegetasi sebagai peredam ingar bunyi khususnya yang dihasilkan oleh kendaraan bermotor.

\section{BAHAN DAN METODE}

\section{Waktu dan Tempat}

Penelitian dilaksanakan pada bulan Februari 2012 hingga Oktober 2012. Bulan April 2012 hingga Juni 2012 pengamatan dilakukan di jalan Metro Pondok Indah, Jakarta Selatan (Lampiran 1), dan bulan Agustus 2012 hingga Oktober 2012 di Laboratorium Anatomi Tumbuhan, Departemen Biologi, FMIPA, IPB.

\section{Bahan}

Alat yang digunakan antara lain Sound Level Meter merek Mastech ${ }^{\circledR}$ MS6701, hand counter, stopwatch, haga altimeter, termometer, rollmeter, alat tulis, dan kamera.

Bahan yang digunakan antara lain bunyi bising, sampel daun yang berada di lokasi, dan alkohol $70 \%$.

Metode

\section{Pengamatan Pendahuluan}

Pengamatan pendahuluan dimaksudkan untuk: melihat kondisi sekitar lokasi sampling

menentukan waktu sampling pada tiap titik sampling menentukan titik sampling

pembagian kategori kendaraan yang akan dihitung

menentukan metode yang tepat untuk mengidentifikasi vegetasi yang tumbuh di lokasi

menentukan alat pendukung lain yang dibutuhkan saat sampling 


\section{Penghitungan Kendaraan Bermotor}

Pembagian ketiga kategori kendaraan didasarkan pada bunyi yang dihasilkan oleh mesin saat melaju. Ketiga kategori kendaraan dihitung dengan menggunakan hand counter. Penghitungan tiga kategori kendaraan selama 15 menit tersebut untuk mewakili jumlah kendaraan selama 1 jam seperti yang direkomendasikan oleh Dinas Lalu Lintas dan Angkutan Jalan Raya (DLLAJR) (Pristiani et al. 2010). Pengamatan dilakukan pada dua hari kerja dan satu hari tibur dengan tiga kali waktu pengamatan, yaitu pagi, siang, dan sore.

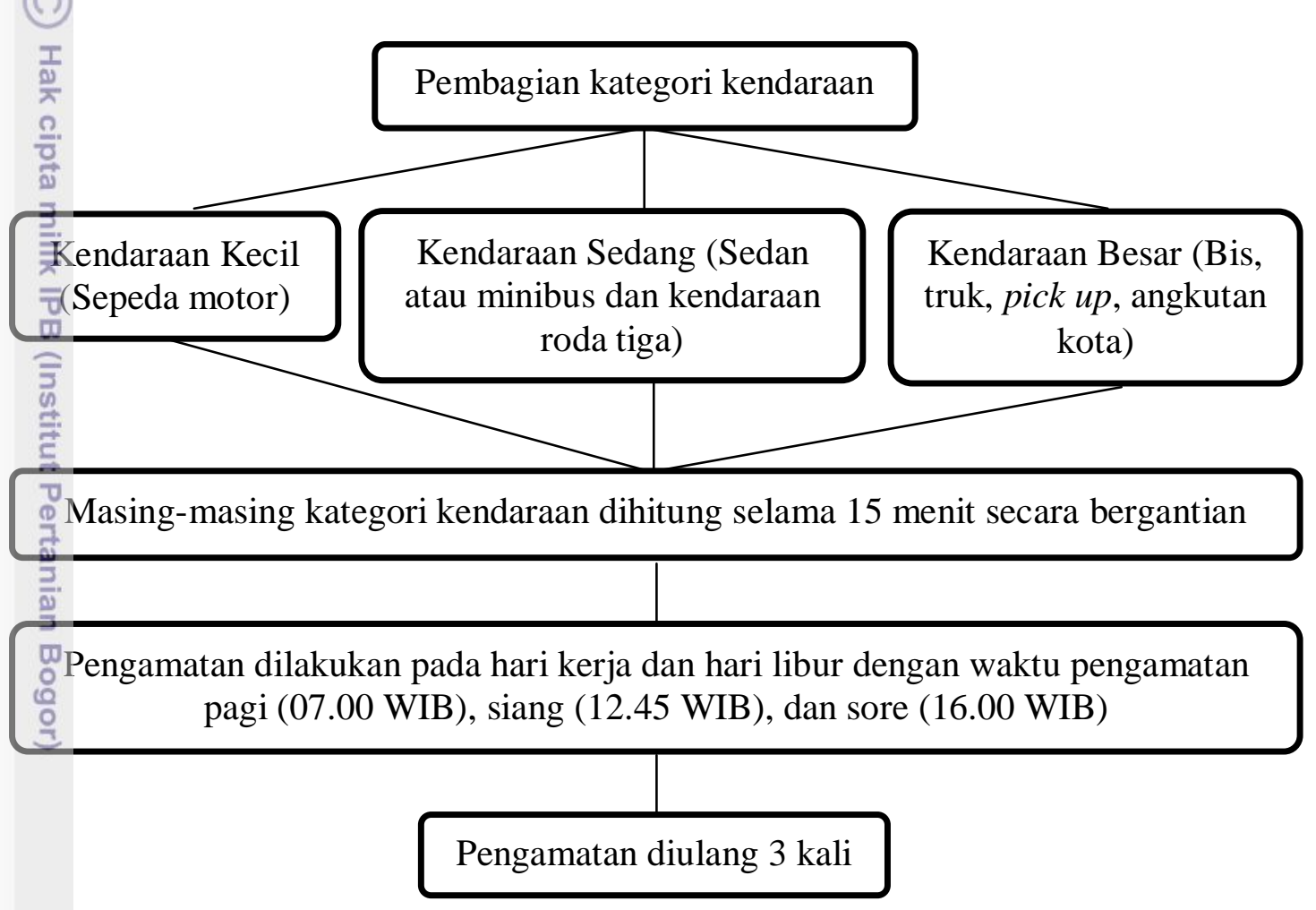

\section{Pengukuran Suhu}

Pengukuran suhu dilakukan sebelum dan sesudah pengukuran intensitas kebisingan. Pengukuran suhu lingkungan dimaksudkan untuk mengetahui apakah suhu berpengaruh dalam perambatan bunyi di udara. Pengukuran suhu dilakukan sebanyak tiga ulangan 


\section{Pengukuran Intensitas Kebisingan}

Intensitas kebisingan diukur menurut gambar sebagai berikut:

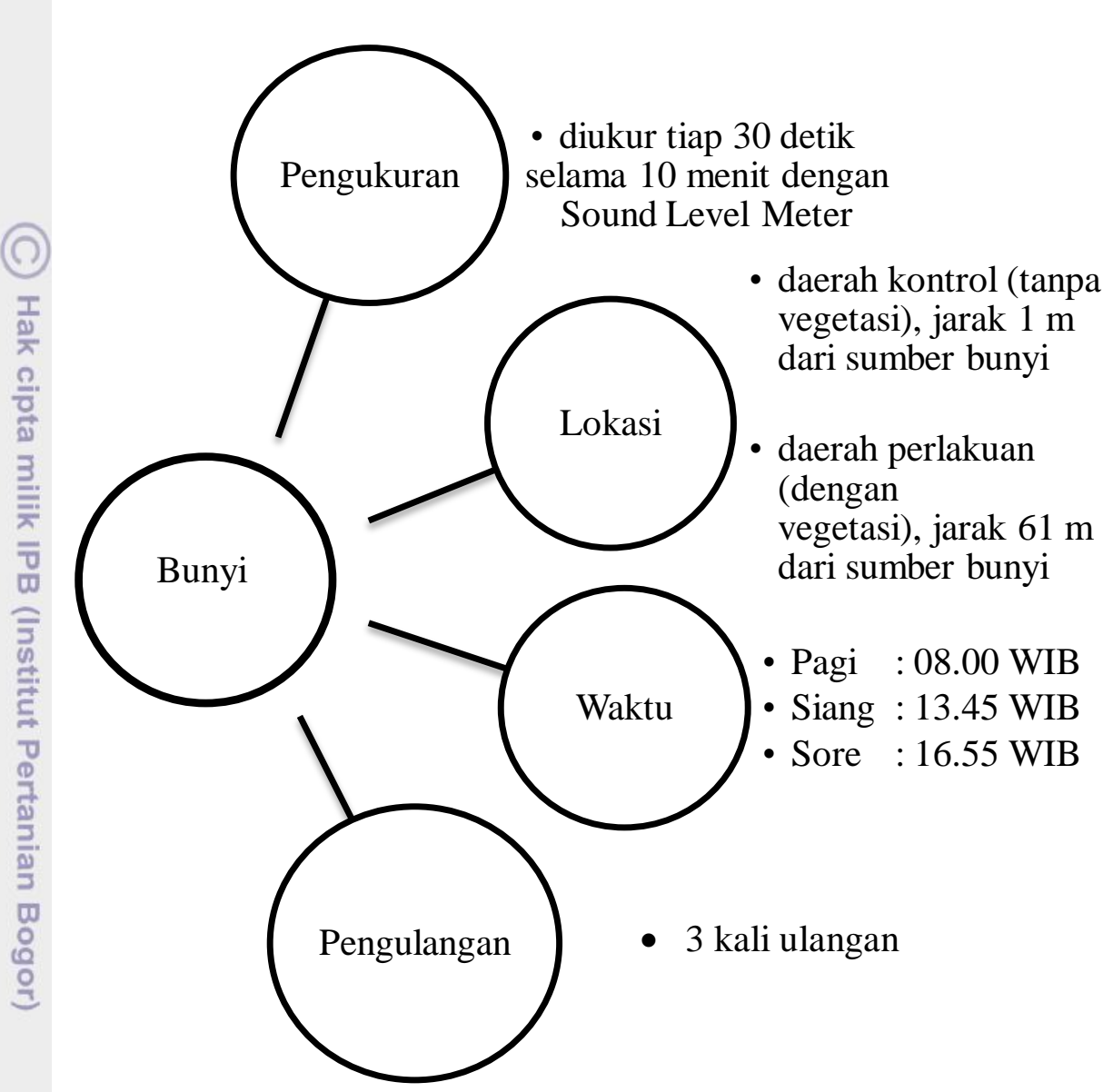

\section{Pengamatan Vegetasi}

Seluruh vegetasi yang diamati berada dalam Ruang Terbuka Hijau (RTH). Pengamatan dilakukan dengan langkah-langkah sebagai berikut:

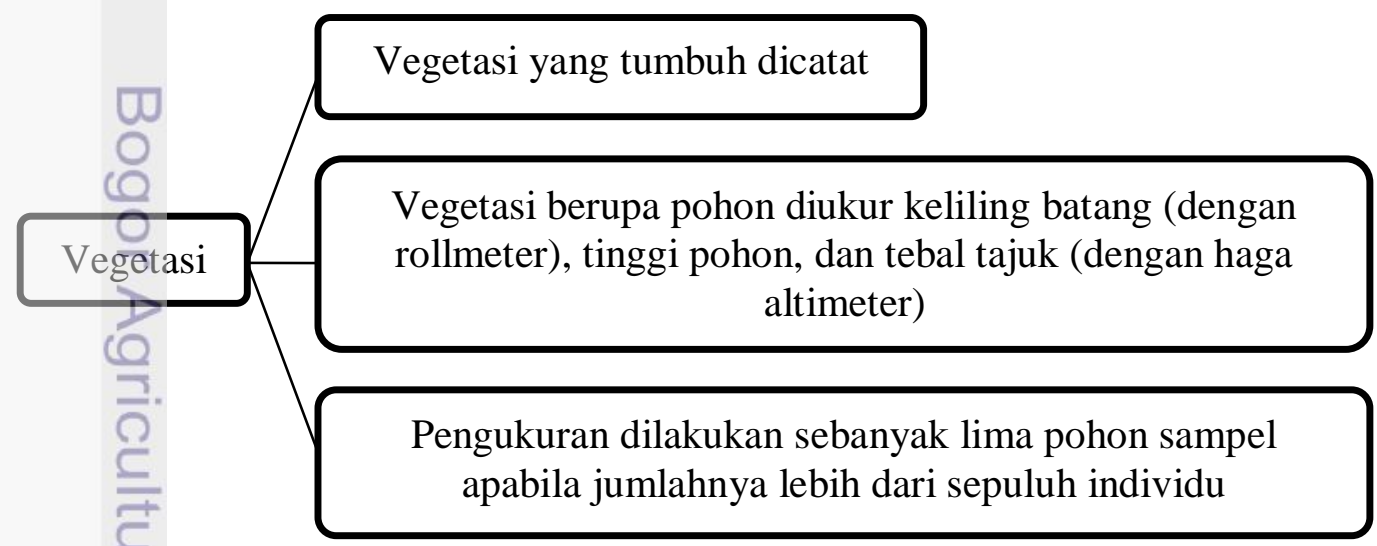




\section{Pengamatan Mikroskopis}

Pengamatan mikroskopis hanya dilakukan untuk individu yang jumlahnya mendominasi dalam RTH. Parameter yang diamati antara lain tebal kutikula adaksial dan abaksial, tebal epidermis adaksial dan abaksial, trikoma, serta jaringan lain apabila ada. Prosedur yang dilakukan sebagai berikut:

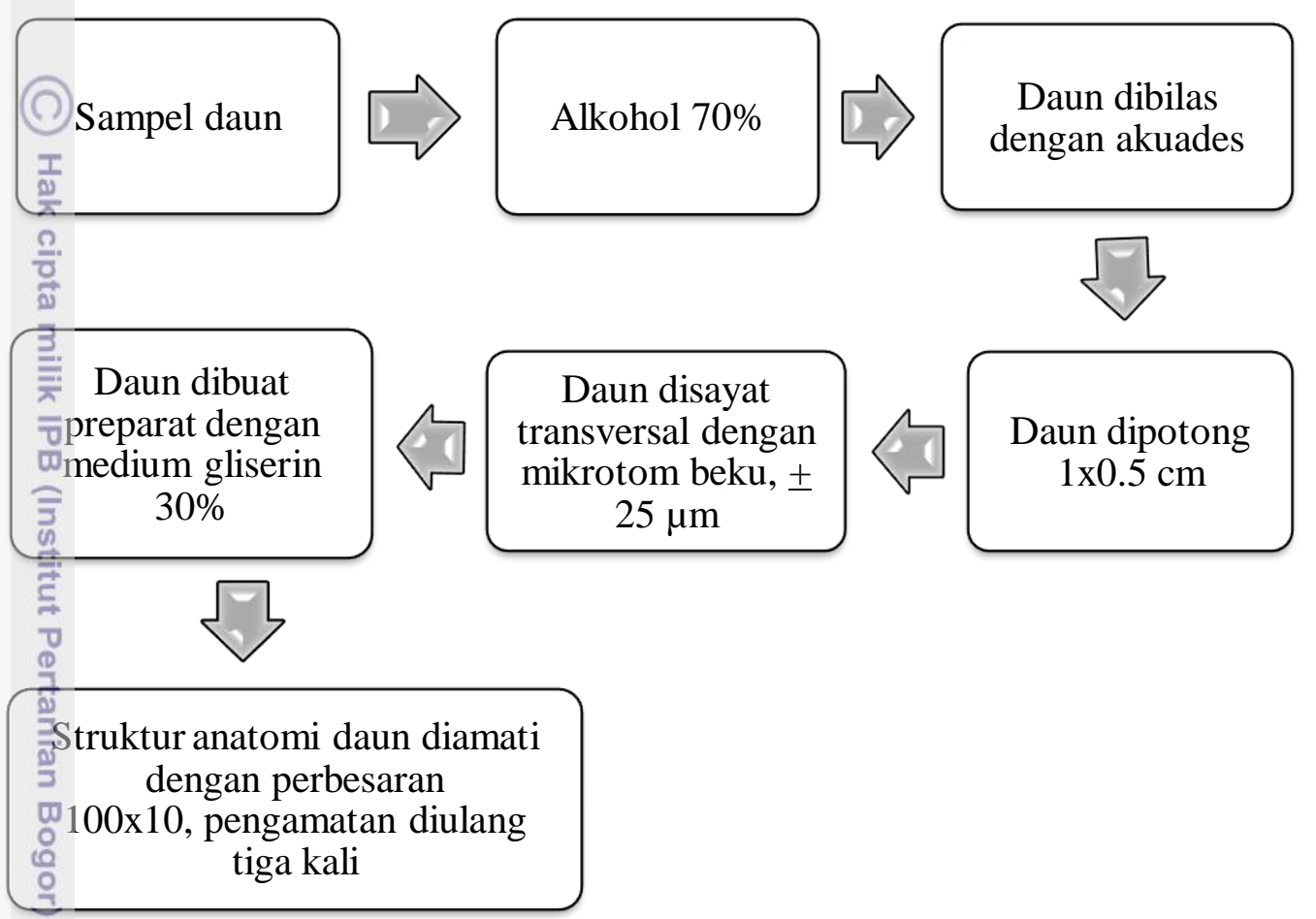

Pembilasan daun dengan akuades harus sampai bersih karena daun yang masih mengandung alkohol akan sulit untuk dibekukan dan dipotong.

\section{Analisis Data}

Agar mendapatkan hasil pengukuran intensitas bising pada waktu yang sama di dua tempat berbeda, maka hasil pengukuran intensitas kebisingan diolah dengan menggunakan formula:

Reterangan:

$$
\mathrm{S} 1-\mathrm{S} 2=10 \log \left(\frac{\mathrm{r} 2}{\mathrm{r} 1}\right)
$$

\$1 = Tingkat bunyi di lokasi $1 /$ kontrol (dBA)

S2 = Tingkat bunyi di lokasi 2/perlakuan (dBA)

= Jarak lokasi 1 terhadap sumber bunyi $(\mathrm{m})$

$=$ Jarak lokasi 2 terhadap sumber bunyi $(\mathrm{m})$

dengan asumsi pengukuran intensitas kebisingan dengan sumber bunyi berbentuk garis (Huboyo \& Sumiyati 2008).

Pengurangan intensitas kebisingan oleh tumbuhan dari jarak $61 \mathrm{~m}$ dapat Giperoleh dengan rumus: 


$$
\beta=10 \log \frac{\mathrm{I}}{\mathrm{I}_{\mathrm{o}}} \mathrm{dBA}
$$

dengan:

$\beta \quad=$ Intensitas bising daerah kontrol hasil perhitungan (dBA) (hasil rumus 1)

I = Intensitas bising daerah kontrol jarak yang sama dengan daerah perlakuan $\left(\mathrm{W} / \mathrm{m}^{2}\right)$

$\mathrm{I}_{\mathrm{O}} \quad=$ Intensitas bising acuan $\left(10^{-12} \mathrm{~W} / \mathrm{m}^{2}\right)$

(Sears \& Zemansky 1962).

Rumu(s) ini digunakan karena pengukuran intensitas bising pada daerah kontrol dilakukan pada jarak yang berbeda dengan pengukuran intensitas bising di daerah perlakư्̛̈an (jarak $61 \mathrm{~m}$ dari sumber bunyi), sehingga dengan rumus ini dapat diperołeh intensitas bising pada daerah kontrol yang diasumsikan berada pada jarak gr m tanpa harus mengukurnya secara langsung.

Eata yang digunakan adalah data hasil pengukuran dengan tiga kali ulangan.

\section{HASIL}

\section{Penghitungan Kendaraan Bermotor}

Apabila dilihat dari tiga waktu pengamatan, hasil penghitungan kendaraan bermotoor menunjukkan bahwa kategori kendaraan yang mendominasi jalan raya saat pagi hari adalah sepeda motor dengan jumlah kendaraan 1518 unit pada hari Sabtu,o1897 unit pada hari Selasa, dan 1839 unit pada hari Rabu. Pada siang dan sore hări, sepeda motor yang melintas berjumlah 880 unit saat siang dan 650 unit saat sore. Dari tiga waktu pengamatan, jumlah kendaraan besar terbanyak terlihat pada hari Rabu siang yaitu sebanyak 86 unit. Jumlah kendaraan sedang terbanyak terlihat saat pagi pada hari Rabu yaitu sebanyak 627 unit kendaraan, dan pada hari Sabtu siang dan hari Selasa siang masing-masing berjumlah 615 unit dan 566 unit (Gambar 1).

Apabila dilihat dari total jumlah kendaraan pada tiga waktu pengamatan, jumlah kendaraan terbanyak terlihat pada pagi hari, dan terbanyak kedua pada siang, dan yang terakhir pada sore hari dengan jumlah masing-masing 2286 unit saat pagi, 1548 unit saat siang, dan 1226 unit saat sore (Lampiran 2). Secara keseluruhan, jumlah kendaraan saat hari kerja (hari Selasa dan Rabu) lebih banyak dibandingkan dengan hari libur (hari Sabtu). 


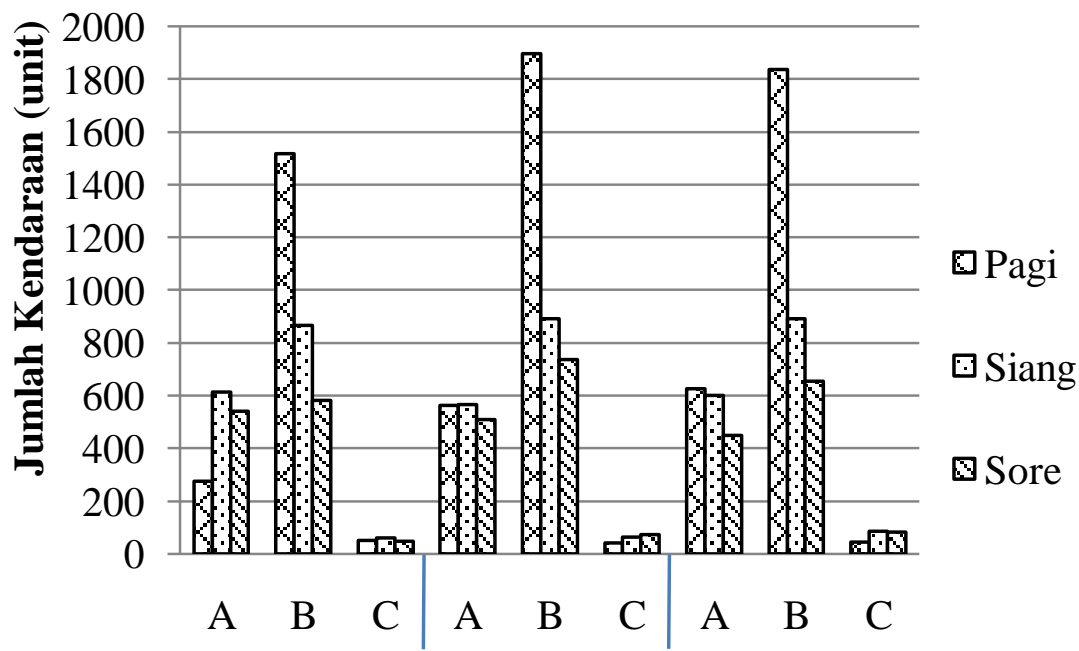

Sabtu Selasa Rabu

\section{Kategori Kendaraan}

Tambar 1 Jumlah masing-masing kategori kendaraan (A: Kendaraan sedang, seperti mobil pribadi (sedan/ minibus) dan kendaraan roda tiga; B: Kendaraan kecil, seperti sepeda motor; C: Kendaraan besar, seperti truk, pick up, bus, dan angkutan kota) pada hari pengamatan.

\section{Pengukuran Suhu}

Hasil pengukuran suhu di daerah kontrol menunjukkan bahwa pada pengukuran awal saat pagi suhu udara berkisar antara $30.0-31.6{ }^{\circ} \mathrm{C}$ dengan suhu tertinggi terjadi pada hari Rabu, sedangkan pada pengukuran akhir suhu udara naik menjadi 31.0-32.0 ${ }^{\circ} \mathrm{C}$ dengan suhu tertinggi terjadi pada hari Selasa dan hari Rabu. Pada pengukuran awal saat siang, suhu udara berkisar antara $35.0-35.7{ }^{\circ} \mathrm{C}$ dengan suhu tertinggi terjadi pada hari Sabtu, sedangkan pada pengukuran akhir suhu udara turun menjadi $34.8-35.6{ }^{\circ} \mathrm{C}$ dengan suhu tertinggi terjadi pada hari Rabu. Pada pengukuran awal saat sore, suhu udara berkisar antara $32.3-33.4{ }^{\circ} \mathrm{C}$ dengan suhu tertinggi dicapai pada hari Selasa, sedangkan pada pengukuran akhir suhu udara turun menjadi 32.3-32.8 ${ }^{\circ} \mathrm{C}$ dengan suhu tertinggi dicapai pada hari Selasa dan hari Rabu (Gambar 2).

Hasil pengukuran suhu di daerah perlakuan menunjukkan bahwa pada pengukuran awal saat pagi suhu berkisar antara 30.5-30.6 ${ }^{\circ} \mathrm{C}$ dengan suhu tinggi terjadi pada hari Selasa, sedangkan pada pengukuran akhir suhu udara berkisar antara 30.7-31.4 ${ }^{\circ} \mathrm{C}$ dengan suhu tertinggi tercapai pada hari Rabu. Pada pengukuran awal saat siang, suhu udara berkisar antara 33.4-34.0 ${ }^{\circ} \mathrm{C}$ dengan suhu tertinggi dicapai pada hari Selasa, sedangkan pada pengukuran akhir suhu udara Fidak berbeda jauh dengan pengukuran awal, yakni berkisar antara 33.5-34.0 ${ }^{\circ} \mathrm{C}$ dengan suhu tertinggi juga dicapai pada hari Selasa. Pada pengukuran awal saat sore suhu udara berkisar antara 31.3-31.5 ${ }^{\circ} \mathrm{C}$ dengan suhu tertinggi dicapai pada hari Rabu, sedangkan pada pengukuran akhir suhu udara naik menjadi 31.4-31.8 @C (Gambar 3). 


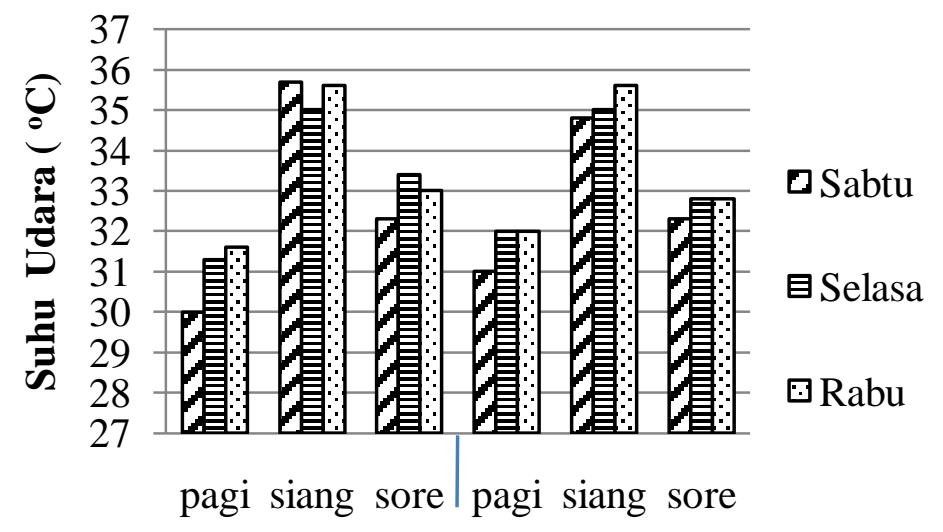

awal akhir

\section{Waktu Pengukuran Suhu}

Gambar 2 Suhu udara di daerah kontrol pada tiga waktu pengamatan.

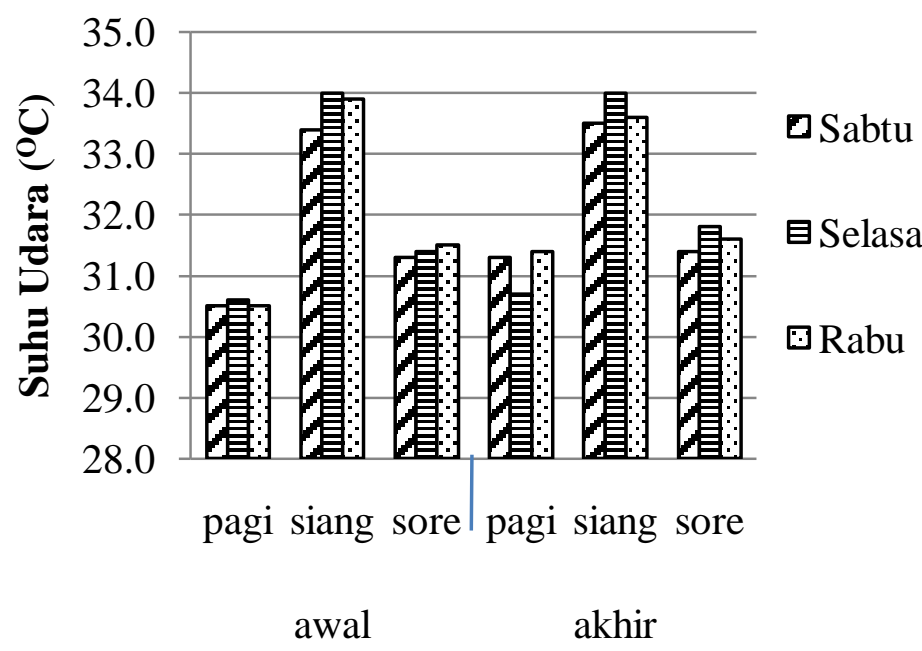

Waktu Pengukuran Suhu

Gambar 3 Suhu udara di daerah perlakuan pada tiga waktu pengamatan.

Hasil pengamatan dalam lampiran 3 memperlihatkan bahwa suhu di daerah perlakuan lebih rendah $0.6-1.6{ }^{\circ} \mathrm{C}$ dibandingkan dengan suhu di daerah kontrol.

\section{Pengukuran Intensitas Kebisingan}

Pengukuran intensitas bising di daerah kontrol dilakukan pada jarak $1 \mathrm{~m}$ dari sumber dan pengukuran di daerah perlakuan dilakukan pada jarak $61 \mathrm{~m}$ dari sumber dengan jarak $60 \mathrm{~m}$ merupakan lebar Ruang Terbuka Hijau (RTH). Berdasarkan Gambar 4, terlihat bahwa intensitas bising di daerah kontrol jauh lebih Tinggi dibandingkan dengan daerah perlakuan, yaitu pada daerah kontrol sebesar-77.3-79.0 dBA dan daerah perlakuan sebesar 56.3-59.4 dBA. Pada daerah 
kontrol, dalam tiga waktu pengukuran yaitu pagi, siang, dan sore, intensitas bising tertinggi terjadi pada hari Sabtu dengan nilai masing-masing 79.0 dBA pada pagi dansore serta $78.2 \mathrm{dBA}$ pada siang. Pada daerah perlakuan, intensitas bising tertinggi terjadi pada hari Rabu pagi dengan nilai intensitas bising sebesar 59.4 dBA, Sabtu siang dengan nilai intensitas bising sebesar 57.0 dBA, dan Rabu sore dengan nilai intensitas bising sebesar $57.8 \mathrm{dBA}$.

Dari data hasil penghitungan intensitas bising di daerah kontrol pada jarak 1 m (Lampiran 4), maka dapat diperoleh nilai intensitas bising pada jarak yang sama dengan daerah perlakuan yaitu $61 \mathrm{~m}$ dari sumber bunyi. Dari hasil perhitungan tersebut, maka dapat diketahui pengurangan intensitas bising oleh Kegetasi yang ada di lokasi pengamatan. Hasil pengurangannya dapat dilihat pada E్Tampiran 5. Berdasarkan Gambar 5, terlihat bahwa saat pagi, intensitas bising berkurang karena adanya vegetasi sebesar 23.0-23.6 dBA dengan pengurangan Rebisingan tertinggi terjadi pada hari Sabtu dan Selasa. Saat siang, intensitas bising berkurang 25.4-26.1 dBA dengan pengurangan kebisingan tertinggi terjadi pàda hari Rabu. Saat sore, intensitas bising berkurang sebesar 24.6-24.9 dBA dengan pengurangan kebisingan tertinggi terjadi pada hari Sabtu dan Selasa. Pengurangan kebisingan paling besar terjadi pada siang hari.

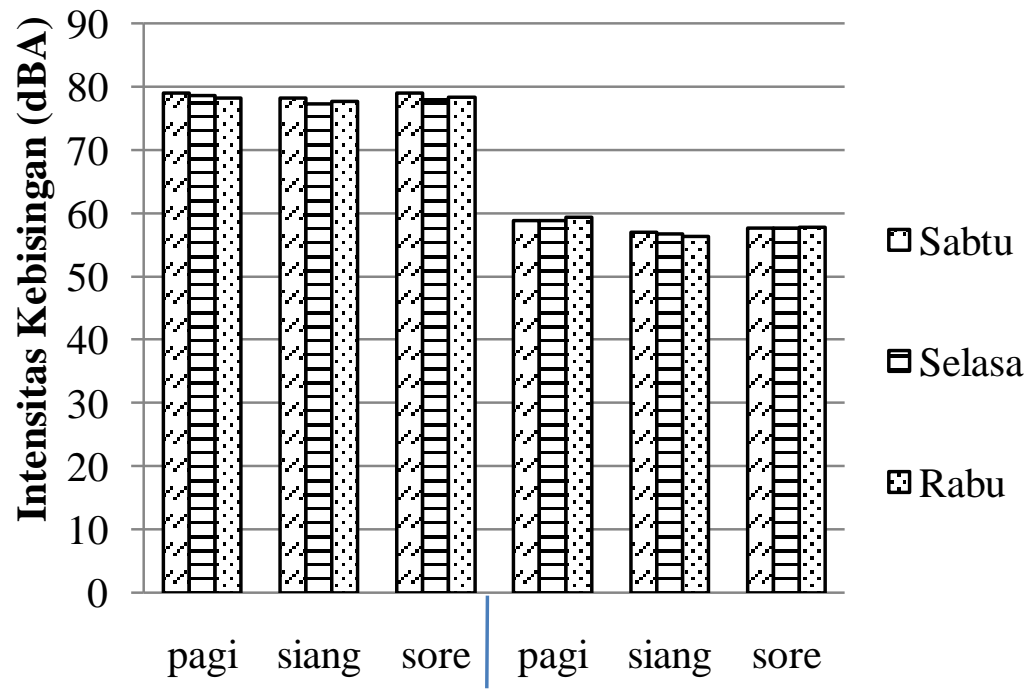

Kontrol

Perlakuan

Waktu Pengukuran Intensitas Kebisingan

Gambar 4 Intensitas bising di daerah kontrol dan daerah perlakuan dalam tiga waktu pengukuran. 


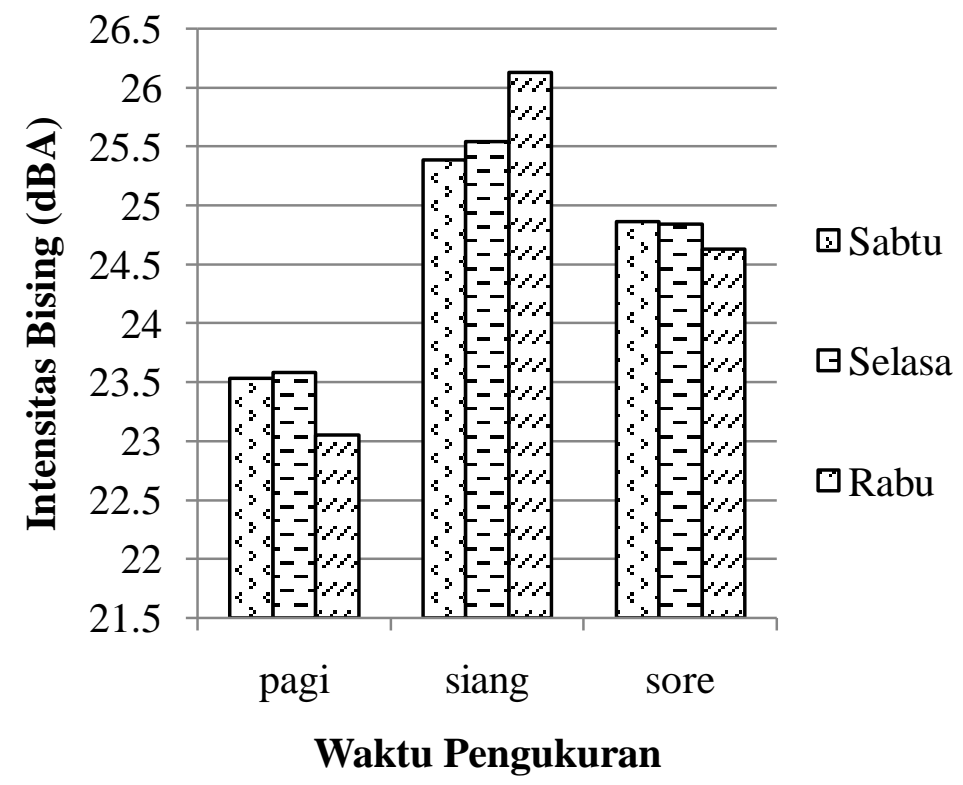

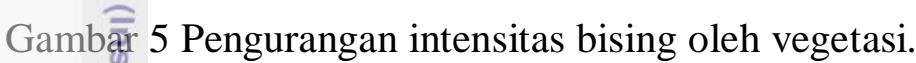

\section{Pengamatan Vegetasi}

Berdasarkan hasil pengamatan, vegetasi yang terdapat di lokasi meliputi Cempäka (Michelia champaca L.), Mahoni (Switenia mahagoni), Bambu (Bambusa sp.), Kelapa (Cocos nucifera), Sengon (Paraserianthes falcataria), Kapuk Randu (Ceiba petandra), Tapak Liman (Elephantopus scaber L.), Kangkungan (Ipoemoea sp.), Rumput Pait (Axonopus sp.) (Gambar 6), Putri Malu (Mimosa pudica), Crotolaria sp., Tanjung (Mimusops elengi), Caladium sp., Oxalis sp., dan Wedelia trilobata. Tumbuhan yang mendominasi di lokasi pengamatan adalah Sengon, yaitu sekitar 80\% RTH. Mahoni dan Cempaka hanya ditanam di sebagian sisi RTH. Kedua tumbuhan ini jumlahnya kurang lebih hanya $10 \%$ dari jumlah vegetasi. Bambu hanya ditanam dipinggir RTH, letaknya berhimpitan dengan pagar yang membatasi RTH dengan jalan raya. Bambu tersebut tidak ditanam di sepanjang pagar pembatas, namun hanya ditanam di sebagian sisi saja. Jumlah batang Bambu dalam satu rumpun tidak sama. Dalam satu rumpun, jumlah batang Bambu ada yang terdiri atas 50-60 batang, sedangkan yang Iain ada yang hanya sekitar 20 batang. Pohon Kelapa yang ada di lokasi hanyåda satu pohon, yang tumbuh di sisi RTH.

Bari seluruh tegakan yang diukur, Kapuk Randu hanya dilakukan dua kali ulangan dari tiga pohon yang ada karena tajuk pohon yang satu menutupi tajuk pohon yang lain, sedangkan keempat pohon lainnya dilakukan lima kali ulangan. Pohom Kelapa tidak dilakukan pengukuran karakteristik fisiognomi karena jumlahnya hanya satu individu. Kapuk Randu merupakan tumbuhan yang memiliki ukuran tinggi total, diameter batang, dan tebal tajuk tertinggi dibanđingkan dengan Mahoni, Cempaka, Bambu, dan Sengon dengan masingmasing parameter sebesar $25.2 \mathrm{~m}$ untuk tinggi total, diameter batang $3.01 \mathrm{~m}$, dan tebal tajuk $18.44 \mathrm{~m}$. Sengon merupakan tegakan dengan ukuran terbesar kedua 
setelah Kapuk Randu. Sengon memiliki tinggi total $24.9 \mathrm{~m}$ dengan diameter batang $1.56 \mathrm{~m}$ dan tebal tajuk $19.37 \mathrm{~m}$ (Lampiran 6).

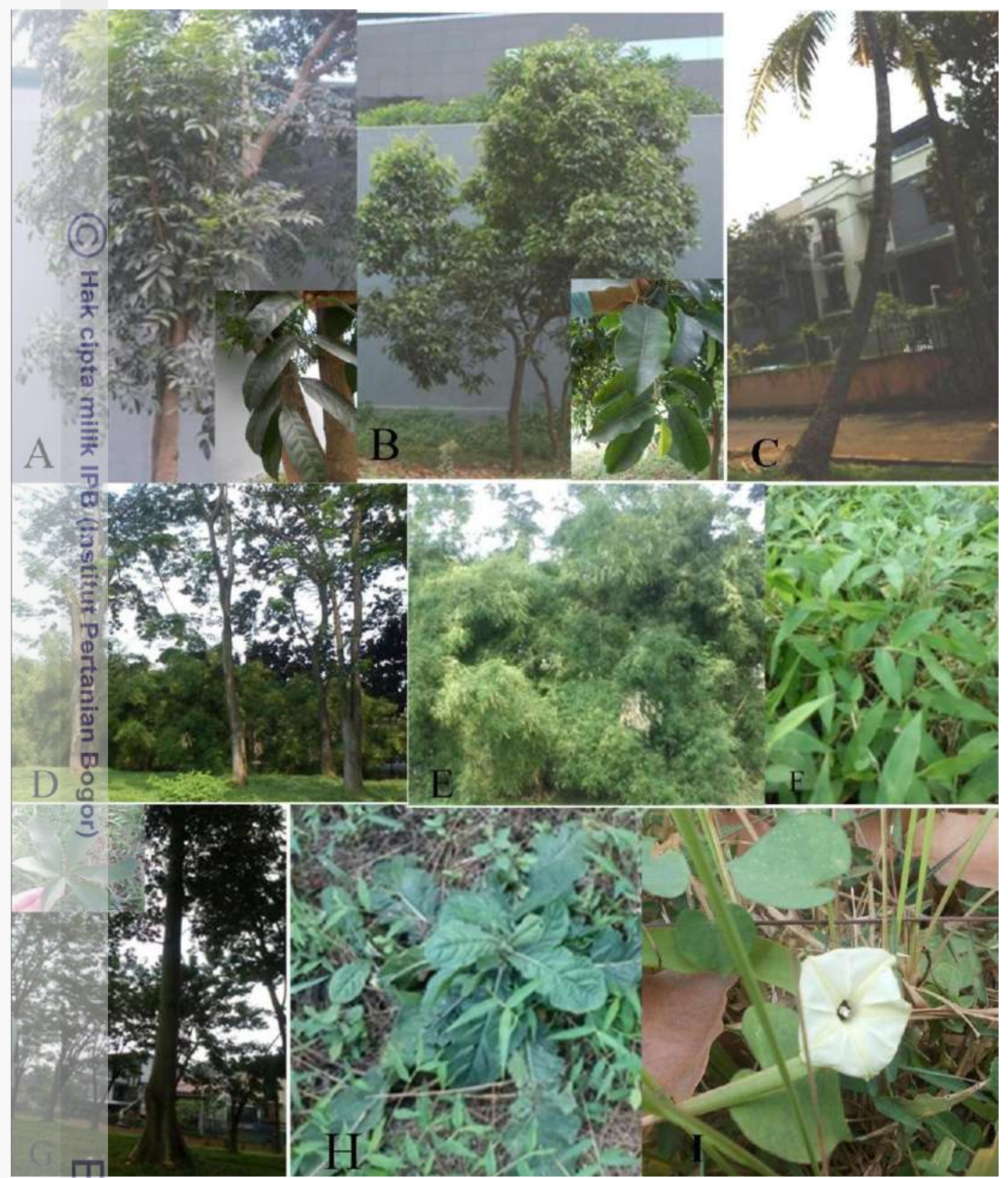

Gambar 6 Vegetasi yang ada di lokasi: A. Mahoni; B. Cempaka; C. Kelapa; D.

(O) Sengon; E. Bambu; F. Rumput Pait; G. Kapuk Randu; H. Tapak

L Liman; I. Kangkungan.

\section{Pengamatan Mikroskopis}

Pengamatan mikroskopis hanya dilakukan pada Sengon, Cempaka, Mahoni, Bambur, dan Rumput Pait. Rumput Pait tumbuh hampir menutupi seluruh permukaan tanah. Tumbuhan bawah lain jumlahnya kurang lebih hanya dua persendari jumlah Rumput Pait. 

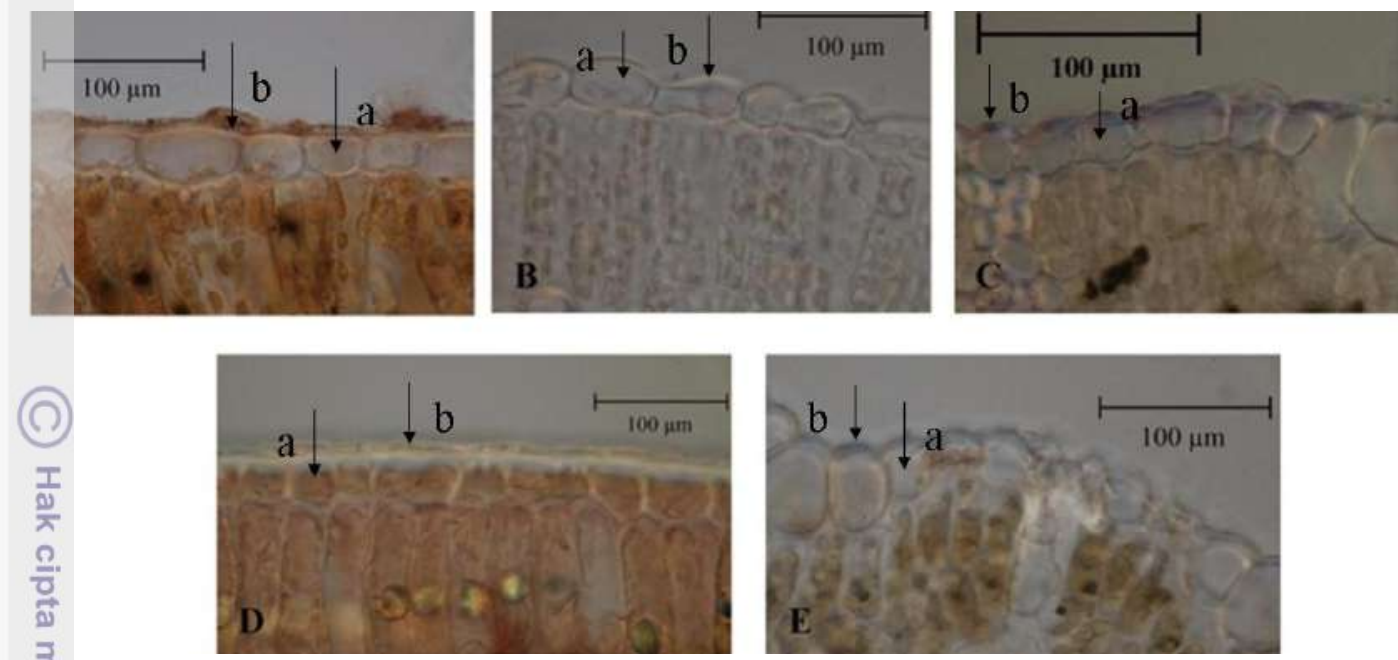

Ġambar 7 Sayatan transversal adaksial: A. Mahoni, B. Sengon, C. Bambu, D. W Cempaka, E. Rumput Pait; (a). epidermis, (b). kutikula (skala $100 \mu \mathrm{m}$ ).

$\widehat{\bar{z}}$

Terlihat bahwa hampir seluruh sampel memiliki kutikula dan epidermis, namun tidak semua tumbuhan memiliki trikoma dan hipodermis (Gambar 7 dan 8). Trikoma hanya ditemukan pada Bambu (Gambar 9) dan jaringan hipodermis hanya ditemukan pada Cempaka (Gambar 10). Tumbuhan bawah yang dilakukan Giamati secara mikroskopis hanya Rumput Pait karena jumlahnya yang miendominasi dalam menutup permukaan tanah. Tebal kutikula adaksial dan abaksial pada Sengon dan Rumput Pait hampir sama yaitu Sengon memiliki tebal kutikula adaksial sebesar $2.22 \mu \mathrm{m}$ dan kutikula abaksial $2.19 \mu \mathrm{m}$, sedangkan Rumput Pait, memiliki kutikula adaksial sebesar $2.5 \mu \mathrm{m}$ dan kutikula abaksial $2.78 \mu \mathrm{m}$ (Lampiran 7).
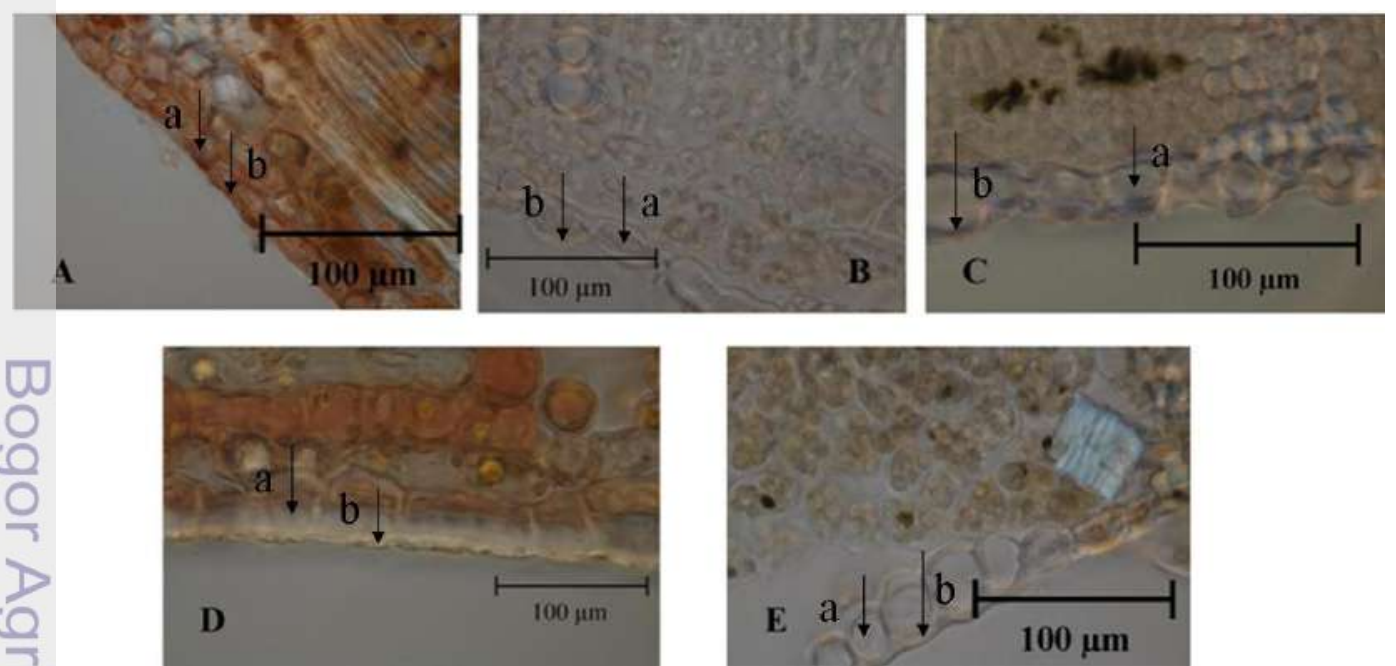

Gambar 8 Sayatan transversal abaksial: A. Mahoni, B. Sengon, C. Bambu, D.

Cempaka, E. Rumput Pait; (a). epidermis, (b). kutikula (skala $100 \mu \mathrm{m}$ ). 


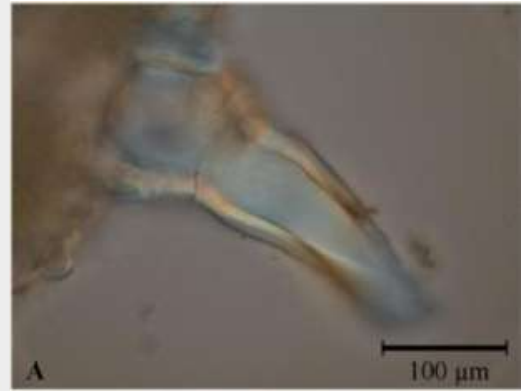

Gambar 9 Sayatan transversal trikoma pada Bambu (skala $100 \mu \mathrm{m}$ ).

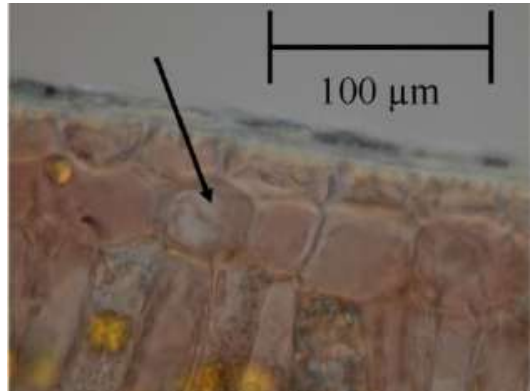

Gambar 10 Jaringan hipodermis pada Cempaka (skala $100 \mu \mathrm{m}$ ).

\section{PEMBAHASAN}

Dari tiga kategori kendaraan, kendaraan yang memiliki jumlah terbanyak addalah sepeda motor. Jumlah sepeda motor selalu terbanyak saat pagi, siang, maupun sore hari, baik pada hari kerja maupun hari libur. Kendaraan sedang (sedan/minibus dan kendaraan roda tiga) adalah kategori kendaraan terbanyak Kedua setelah sepeda motor. Pada hari kerja, jumlahnya lebih banyak dibandingkan dengan hari libur. Kategori kendaraan besar jumlahnya paling sedikit điantara dua kategori yang lain, pada hari kerja maupun pada hari libur, baik saat pagi, siang, maupun sore (Gambar 1).

Hasil pengukuran intensitas kebisingan menunjukkan bahwa kebisingan di đaerah kontrol berkisar antara 77.3-79.0 dBA (Lampiran 4). Angka tersebut lebih besar 12-14 dBA dari baku mutu tingkat kebisingan. Daerah kontrol merupakan kawasan Perkantoran dan Perdagangan dengan baku mutu kebisingan yang diperbolehkan adalah $65 \mathrm{dBA}$. Intensitas bising di daerah perlakuan berkisar antara 57.0-58.9 dBA pada Sabtu dan 56.3-59.4 dBA pada hari kerja (Lampiran 4). Hasil tersebut lebih tinggi 2-3 dBA dari baku mutu tingkat kebisingan. Daerah perlakuan merupakan kawasan Perumahan dan Pemukiman dengan baku mutu kebisingan yang diperbolehkan hanya sebesar $55 \mathrm{dBA}$. Hasil pengukuran di kedua tempat tersebut telah melebihi nilai baku mutu kebisingan seperti yang telah ditetapkan oleh Menteri Negara Lingkungan Hidup No. 48 tahun 1996 tentang Baku Tingkat Kebisingan. Baku Tingkat Kebisingan adalah batas maksimal tingkat kebisingan yang diperbolehkan dibuang ke lingkungan dari usaha atau kegiatan sehingga tidak menimbulkan gangguan kesehatan manusia dan knenyamanan lingkungan (Palupi \& Rusjadi 2011). Baku Tingkat Kebisingan yang ditetapkan oleh Kementerian Negara Lingkungan Hidup tersaji pada Lampiran 8.

Berdasarkan Lampiran 6, intensitas bising di daerah kontrol pada jarak yang Sama dengan pengukuran intensitas bising di daerah perlakuan yaitu $61 \mathrm{~m}$ berada dălam kisaran angka $82 \mathrm{dBA}$. Angka tersebut lebih besar 3-5 dBA dibandingkan dengan pengukuran dari jarak $1 \mathrm{~m}$ yang memiliki intensitas bising sekitar 77.3$79.0 \mathrm{dBA}$. Hal tersebut juga dapat disebabkan oleh jarak tanam yang cukup lebar sehingga memungkinkan bunyi bising dapat menembus barisan kanopi (Hidayat 2010). Pengurangan intensitas bising oleh vegetasi saat pagi berkisar antara 23.023.6 dBA dengan pengurangan terbesar terjadi pada hari Sabtu dan Selasa. Saat 
siang, pengurangan intensitas bising oleh vegetasi berkisar antara 25.4-26.1 dBA dengan pengurangan terbesar terjadi pada hari Rabu. Saat sore, pengurangan intensitas bising oleh vegetasi berkisar antara 24.6-24.9 dBA dengan pengurangan bising terbesar terjadi pada hari Sabtu dan Selasa. Hasil tersebut berkaitan dengan jumlah kendaraan pada hari Sabtu yang lebih sedikit yaitu sekitar 1500 unit dibandingkan dengan jumlah kendaraan yang hampir mencapai 2000 unit pada hari kerja.

Diantara tiga waktu pengukuran, saat siang hari merupakan pengurangan intensitas bising terbesar dibandingkan dengan pada saat pengukuran pagi dan sore hari karena sinar matahari sudah cukup terik sehingga menyebabkan partikel udara דె partikę udara rapat, maka bunyi akan cepat merambat karena jarak antar partikel berdekatan, seperti pada malam hari. Namun, apabila partikel udara renggang, maka Bunyi akan merambat dengan lambat karena jarak antar partikel berjauhan, sepert㞷pada siang hari (Hidayati 1994). Apabila dilihat dari jumlah kendaraan yang terhitung dan intensitas bising hasil pengukuran yang diperoleh, maka jumlahokendaraan tidak terlalu berpengaruh dalam menghasilkan intensitas bising yang besar. Dalam penelitian ini, yang memberikan pengaruh yang cukup besar dalam enaikan intensitas bising adalah suhu udara.

Suhu udara saat siang hari terlihat cukup tinggi di kedua tempat pengukuran. Hal in disebabkan oleh proses konveksi bebas. Pada konveksi bebas, udara dipanask kan oleh permukaan bumi akibat penerimaan radiasi surya, sehingga udara akan mengembang naik, dan menuju ke tekanan yang lebih rendah (Hidayati 1994). Proses ini menyebabkan partikel udara merenggang, dan menyebabkan bunyi Jang merambat melaluinya menjadi berkurang. Hal ini terjadi pada daerah perlakban yang memiliki suhu udara lebih rendah dibandingkan dengan daerah kontrof. Hal ini disebabkan oleh adanya vegetasi yang mampu menurunkan suhu udara sekitarnya, sehingga menyebabkan suhu udara di daerah perlakuan lebih rendah dari suhu di daerah kontrol.

Suhu udara di daerah kontrol saat Sabtu pagi cukup hangat yaitu 30.0-31.0 ${ }^{\circ} \mathrm{C}$, namun saat siang suhu naik menjadi $35.7^{\circ} \mathrm{C}$ pada pengukuran awal dan turun menjadi $34.8{ }^{\circ} \mathrm{C}$ pada pengukuran akhir. Saat sore, suhu udara stabil, yaitu $32.3{ }^{\circ} \mathrm{C}$ (Gambar 2). Suhu udara yang stabil disebabkan suhu udara di tempat itu lebih dingin dari suhu disekitarnya, sehingga tidak terjadi gerakan naik pada kantong udara. Pada hari kerja suhu udara lebih tinggi dibandingkan dengan hari libur. Hal ini dikarenakan suhu udara lebih hangat dari suhu sekitarnya sehingga kantong udara akan terus naik (Hidayati 1994). Pada hari kerja suhu udara lebih tinggi dibandingkan hari libur. Hal ini dikarenakan suhu kantong udara lebih hangat dari suhu fingkungan sehingga kantong udara akan terus naik (Hidayati 1994). Apabila kantong udara tidak naik, maka laju rambat bunyi cepat. Sebaliknya, apabila kantong udara naik, maka laju rambat bunyi lambat.

Tingkat kebisingan yang dikeluarkan oleh kendaraan tidak hanya berasal dari mesin, namun juga berasal dari knalpot dan pergesekan antara ban dengan permukaan jalan. Jadi, tingkat kebisingan lalu lintas sangat bergantung pada volume kendaraan, kecepatan kendaraan, jenis permukaan lintasan, serta jenis kendaraan yang melintas (Indoria 2009).

Sengon adalah tegakan yang ditanam paling banyak di RTH. Sengon memiliki struktur daun yang kecil sehingga memiliki luas permukaan daun yang 
lebih luas dibandingkan dengan tanaman lainnya. Struktur tersebut sangat membantu dalam penyerapan bunyi di udara. Hal ini didukung oleh Yuliarti (2002) yang menyatakan bahwa Pinus efektif dalam meredam bunyi. Pinus memiliki struktur daun yang dekat dengan Sengon, yaitu berdaun sempit tetapi jumlah daun pada pohon lebih banyak sehingga memiliki total luas permukaan daun yang lebih luas dibandingkan dengan tanaman yang berdaun lebar. Selain itu, Sengon juga memiliki tinggi hampir $25 \mathrm{~m}$ dengan keliling batang $1.5 \mathrm{~m}$, tebal tajuk yang hampir $20 \mathrm{~m}$, dan ditanam secara berlapis. Hal tersebut juga sangat membantu dalam peredaman kebisingan. Tumbuhan Bambu memiliki daun yang cetkup lebat. Daun Bambu tumbuh menutupi batangnya. Meskipun Bambu hanya đitanam di sebagian sisi RTH, namun ketebalan rumpun yang mencapai 50-60 Б్ timbuh dengan cepat dan menutupi hampir seluruh permukaan tanah juga membantu dalam peredaman kebisingan.

Lampiran 7 menunjukkan bahwa dari lima tumbuhan yang diamati, Cempaka memiliki ukuran tebal kutikula dan epidermis adaksial dan abaksial terbesar. Pada Cempaka, jaringan hipodermis terlihat pada anatomi daun, sedangkan pada Bambu, terlihat dengan adanya trikoma. Selain trikoma yang terrlihat saat pengamatan mikroskopis, trikoma pada Bambu juga terdapat pada $\vec{p}$ ermukaan daunnya yang apabila permukaan daunnya diraba, maka akan terasa rambut-rambut halus yang menutupi permukaan daunnya. Menurut Erdogan dan Xazgan (2009), setiap bagian tumbuhan efektif dalam menyerap dan menyebarkan bunyi. Dalam penelitian ini, diperkirakan kutikula, epidermis, dan trikoma juga berperan dalam peredaman bunyi.

"ू. Onder dan Kockeber (2012) menjelaskan bahwa tanaman yang digunakan Galam meredam bising sebaiknya bervariasi, terdiri atas pohon dengan berbeda ketinggian. Selain itu, tanaman evergreen atau tanaman yang hijau sepanjang tahun juga sebaiknya digunakan. Tanaman yang berukuran besar dengan daun yang panjang, memiliki tekstur yang keras, dan rantingnya mencapai tanah juga dapat digunakan sebagai pilihan. Peredaman bising oleh tanaman akan lebih efisien apabila dipadukan dengan dinding pembatas bermaterial keras (Onder \& Kockeber 2012). Keefektifan peredaman bising oleh tanaman ditentukan oleh jenis tanaman yang ditanam dengan urutan tanam mulai dari herba, semak, perdu, dan terakhir pohon.

\section{SIMPULAN DAN SARAN}

Pengurangan intensitas bising oleh vegetasi berkisar antara 25.4-26.1 dBA (đengan pengurangan bising terbesar terjadi pada hari Rabu siang. Intensitas Kebisingan sangat dipengaruhi oleh suhu. Apabila suhu tinggi, intensitas bising berkurang, dan apabila suhu menurun, intensitas bising lebih tinggi. Vegetasi berperan dalam peredaman bunyi walaupun intensitas bising yang terukur di Iokasi penelitian masih melebihi baku mutu kebisingan. Keefektifan peredaman bising oleh tanaman ditentukan oleh jenis tanaman yang ditanam dengan urutan tanam mulai dari herba, semak, perdu, dan pohon. 
Sebaiknya, vegetasi yang ditanam lebih bervariasi dengan syarat tanaman tersebut memiliki kanopi yang lebat. Agar peredaman bunyi lebih efektif, maka kombinasi antara vegetasi dan dinding pembatas dapat digunakan.

\section{DAFTAR PUSTAKA}

BergerEH, Casali JG. 1998. Hearing Protection Device. Di dalam: Crocker MJ, editor. A Handbook of Accoustic. New York: J Wiley. hlm 798-802.

Chaeraึ M. 2008. Kajian kebisingan akibat aktivitas di bandara (studi kasus banflara Ahmad Yani Semarang) [tesis]. Semarang: Program Pascasarjana, Universitas Diponegoro.

Erdogaైn E, Yazgan ME. 2009. Landscaping in reducing traffic noise problem in cities: Ankara case. Afr. J. Agric. Res. 4: 1015-1022.

Hiday $\overline{\bar{a}}$ IW. 2010. Kajian fungsi jalur hijau jalan sebagai penyangga lingkungan pada tol Jagorawi. J. Manus. dan Lingk. 17:124-133.

Hidayẳi R. 1994. Pembentukan awan dan hujan. Di dalam: Handoko, editor. Klimatologi Dasar. Bogor: Pustaka Jaya.

Huboy HS, Sumiyati S. 2008. Buku Ajar Pengendalian Bising dan Bau. Serharang: Universitas Diponegoro.

Indoria RP. 2009. Towards reducing noise pollution on the highway. Indian Highwas 2-3. [terhubung berkala].http://irc.org.in/ENU/knowledge/Editorial/June\% 202009.pdf [2 Mei 2013].

Onderôs, Kockeber Z. 2012. Importance of green belts to reduce noise pollution andidetermination of roadside noise reduction effectiveness of bushes in Konya, Turkey. World Academy of Science 66: 639-642.

Palupi MR, Rusjadi D. 2011. Kajian metode sampling pengukuran kebisingan dari keputusan menteri lingkungan hidup no. 48 tahun 1996. J. Standar 13 (3): 176183.

Pristiani M, Kamil IM, Putra IBA. 2010. Tingkat ketergangguan masyarakat akibat kebisingan lalu lintas pada jalan Plum-pang Raya. [terhubung berkala]. http://www.ftsl.itb.ac.id/kk/teknologi_pengelolaan_lingkungan/wpcontent/uplo ads/2010/ 10/PI-EH3-Mita-Pristiani-15305075.pdf. [18 November 2011].

Sears FW, Zemansky MW. 1962. University of Physics. Massachu-setts: Wesley Publishing.

[WHO] World Health Organization. 2012. Burden of disease from environmental noise.[terhubungberkala].http://www.euro.who.int/data/assets/pdf_file/0008/ 136466/e94888.pdf [7 Juni 2013].

Yang E, Bao ZY, Zhu ZJ. 2011. An assessment of psychological noise reduction by đandscape plants. Int. J. Environ. Res. Public Health 8: 1032-1048.

Yuliarti. D. 2002. Karakteristik tanaman yang efektif mereduksi kebisingan [skripsi]. Bogor: Fakultas Pertanian, Institut Pertanian Bogor. 


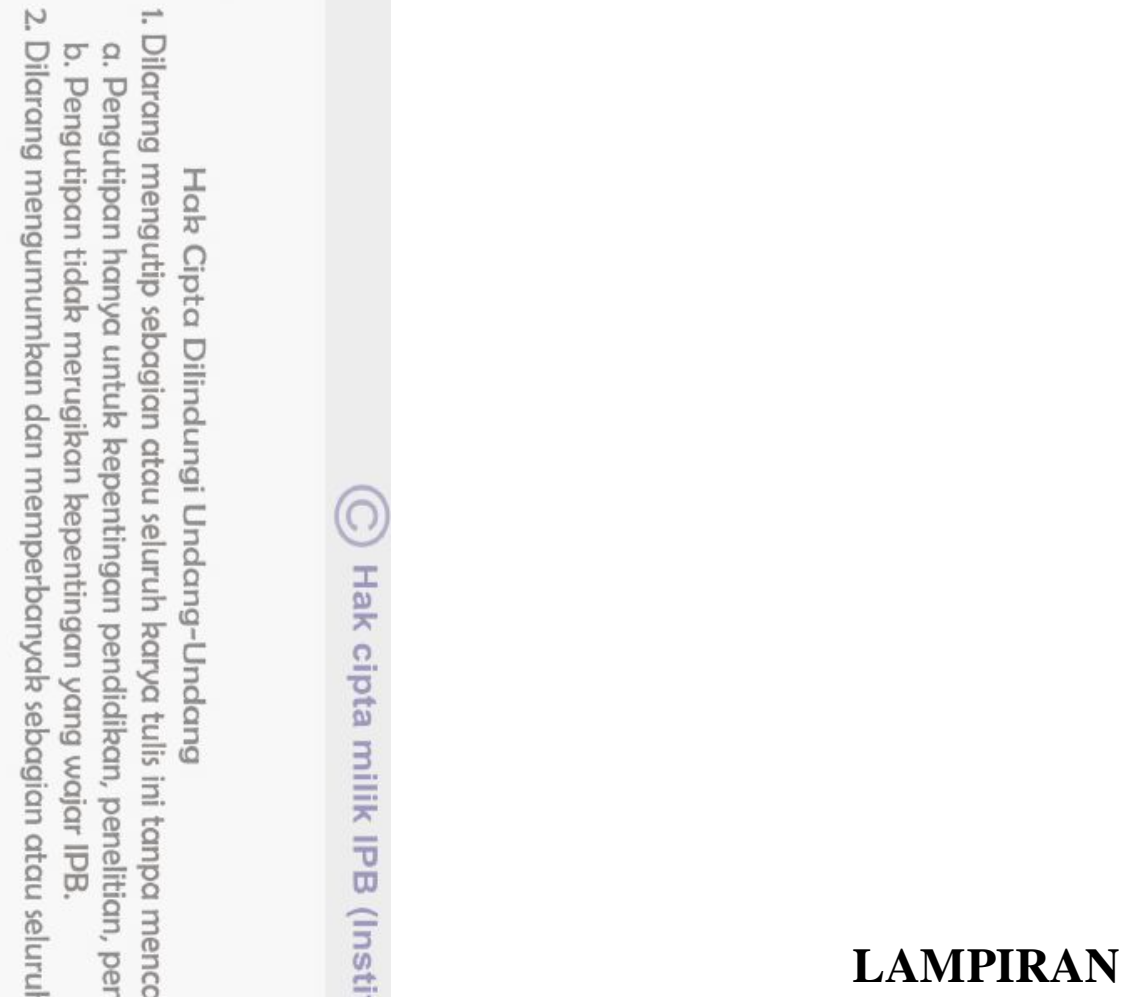




\section{(ist)}

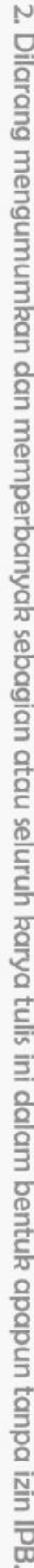

Lampiran 1 Lokasi pengamatan

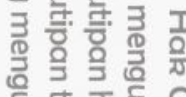

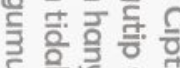

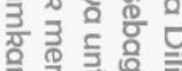

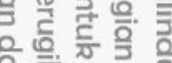

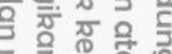

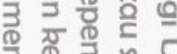

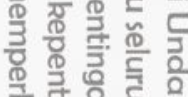

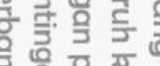

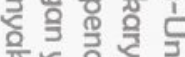

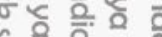

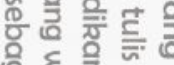

응. 을

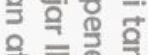

율 可嘼产

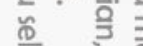

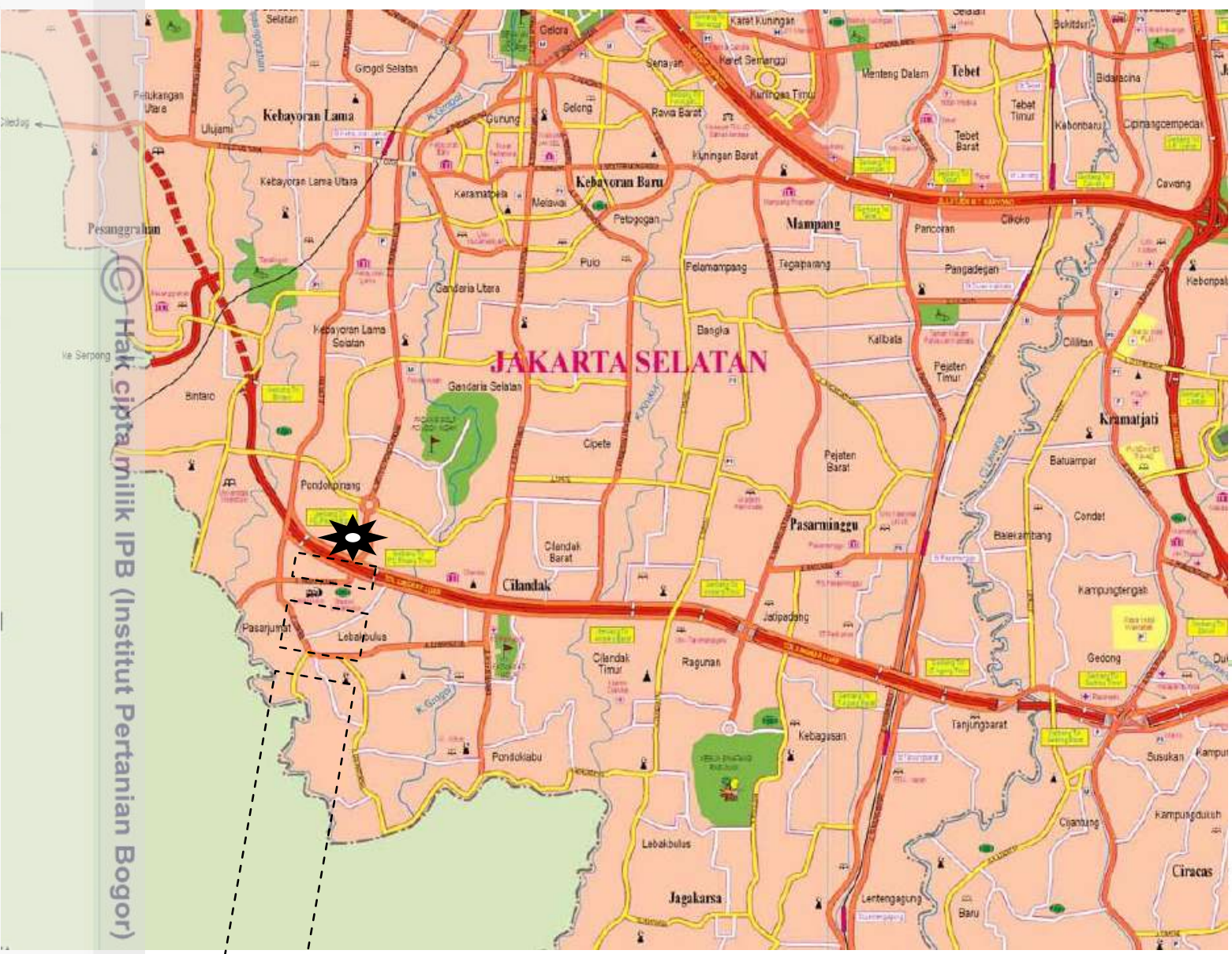

Sumber: http://saripediá.files.wordpress.com/2010/11/dki.jpg

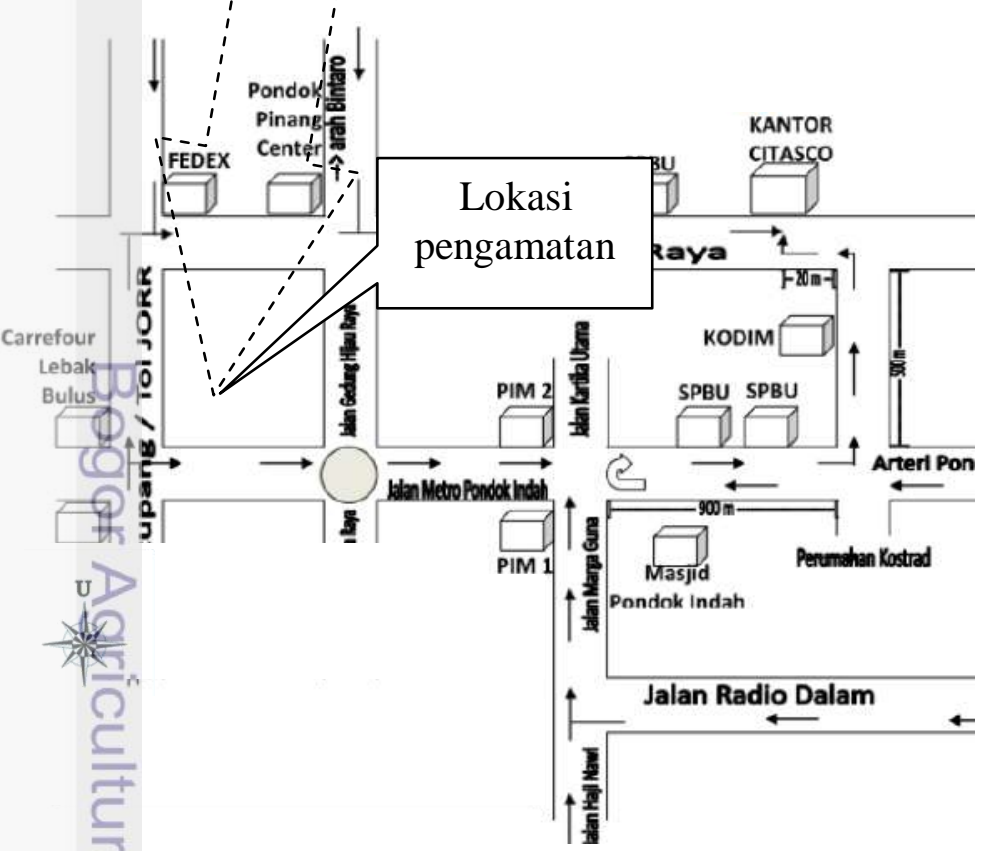

Sumber: http://www.citasco.com/files/images/xsim/peta.jpg 
Lampiran 2 Jumlah kendaraan pada tiga waktu pengamatan

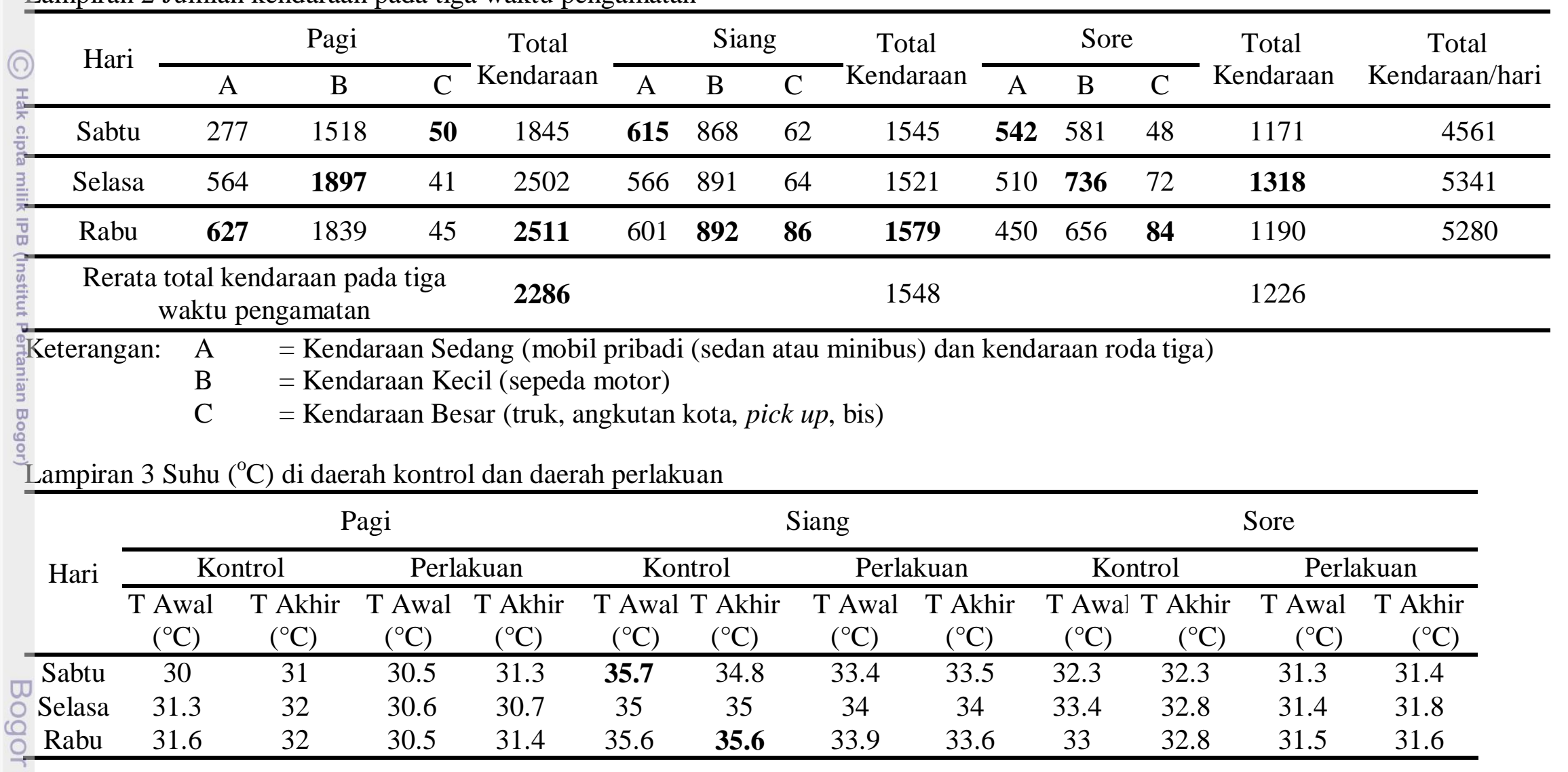


Lampiran 4 Intensitas kebisingan (dBA) di daerah kontrol dan daerah perlakuan

\begin{tabular}{|c|c|c|c|c|c|c|c|}
\hline & \multirow{2}{*}{ Hari } & \multicolumn{2}{|c|}{ Pagi } & \multicolumn{2}{|c|}{ Siang } & \multicolumn{2}{|c|}{ Sore } \\
\hline O & & Kontrol & Perlakuan & Kontrol & Perlakuan & Kontrol & Perlakuan \\
\hline & Sabtu & 79.0 & 58.9 & 78.2 & 57.0 & 79.0 & 57.6 \\
\hline పే & Selasa & 78.6 & 58.9 & 77.3 & 56.8 & 78.0 & 57.6 \\
\hline$\underline{3}$ & Rabu & 78.2 & 59.4 & 77.7 & 56.3 & 78.4 & 57.8 \\
\hline
\end{tabular}

Lampiran 5 Intensitas bising (dBA) di daerah kontrol dan daerah perlakuan pada jarak $61 \mathrm{~m}$ dan pengurangannya oleh vegetasi

\begin{tabular}{|c|c|c|c|c|c|c|c|c|c|}
\hline \multirow{2}{*}{ Hari } & \multicolumn{2}{|c|}{ Pagi } & \multirow{2}{*}{$\Delta$} & \multicolumn{2}{|c|}{ Siang } & \multirow{2}{*}{$\Delta$} & \multicolumn{2}{|c|}{ Sore } & \multirow{2}{*}{$\Delta$} \\
\hline & Kontrol & Perlakuan & & Kontrol & Perlakuan & & Kontrol & Perlakuan & \\
\hline Sabtu & 82.5 & 58.9 & 23.6 & 82.4 & 57.0 & 25.4 & 82.5 & 57.6 & 24.9 \\
\hline Selasa & 82.5 & 58.9 & 23.6 & 82.4 & 56.8 & 25.6 & 82.4 & 57.6 & 24.9 \\
\hline Rabu & 82.4 & 59.4 & 23.0 & 82.4 & 56.3 & 26.1 & 82.4 & 57.8 & 24.6 \\
\hline
\end{tabular}

Lampiran 6 Ukuran karakteristik fisiognomi tumbuhan tegak yang berada di lokasi pengamatan

\begin{tabular}{ccccc}
\hline $\begin{array}{c}\text { Nama } \\
\text { Tumbuhan }\end{array}$ & $\begin{array}{c}\text { Tinggi Total } \\
(\mathrm{m})\end{array}$ & $\begin{array}{c}\text { Tinggi Batang } \\
\text { Bebas Tajuk }(\mathrm{m})\end{array}$ & $\begin{array}{c}\text { Tebal Tajuk } \\
(\mathrm{m})\end{array}$ & $\begin{array}{c}\text { Keliling Batang } \\
(\mathrm{m})\end{array}$ \\
\hline Sengon & 24.9 & 3.92 & 19.37 & 1.56 \\
Cempaka & 10.58 & 1.58 & 7.39 & 0.99 \\
Mahoni & 6.56 & 0.66 & 4.29 & 0.59 \\
Bambu & 8.56 & 0 & 8.56 & 0.08 \\
Kapuk Randu & 25.2 & 5.15 & 18.44 & 3.01 \\
\hline
\end{tabular}


Lampiran 7 Tebal kutikula (adaksial dan abaksial) dan epidermis (adaksial dan abaksial)

\begin{tabular}{|c|c|c|c|c|c|c|}
\hline (๑) & Sampel & $\begin{array}{c}\text { Kutikula } \\
\text { Adaksial }(\mu \mathrm{m})\end{array}$ & $\begin{array}{c}\text { Kutikula } \\
\text { Abaksial }(\mu \mathrm{m})\end{array}$ & $\begin{array}{c}\text { Epidermis } \\
\text { Adaksial }(\mu \mathrm{m})\end{array}$ & $\begin{array}{c}\text { Epidermis } \\
\text { Abaksial }(\mu \mathrm{m})\end{array}$ & Keterangan \\
\hline$T$ & Sengon & 2.22 & 2.19 & 8.89 & 10.28 & \\
\hline$\stackrel{\pi}{\varrho}$ & Cempaka & 4.72 & 5.28 & 10.28 & 10.14 & \\
\hline 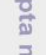 & Mahoni & 4.44 & 2.42 & 8.06 & 8.33 & \\
\hline 竞: & Bambu & 0.92 & 1.81 & 5.36 & 7.08 & Daun dengan trikoma \\
\hline$\overline{\bar{z}}$ & Rumput Pait & 2.5 & 2.78 & 7.5 & 12.78 & \\
\hline
\end{tabular}


Lampiran 8 Baku mutu kebisingan

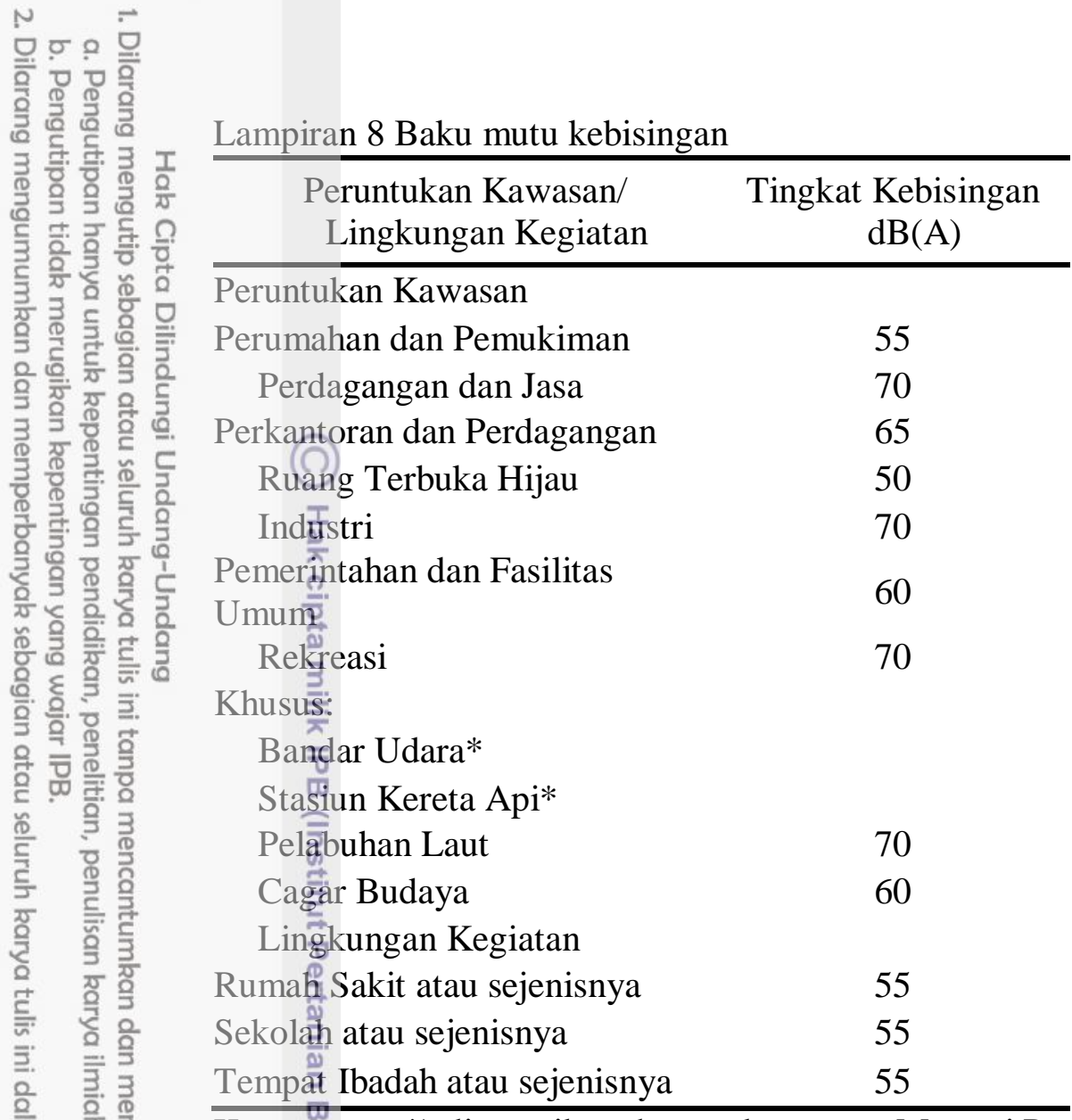

Keterangan: *) disesuaikan dengan ketentuan Menteri Perhubungan Sumber: Menteri Negara Lingkungan Hidup 1996 


\section{RIWAYAT HIDUP}

Penulis dilahirkan di Tangerang pada tanggal 19 September 1989 dari pasangan Bapak Chuzaini Anis dan (alm.) Ibu Adi Sasaminingsih. Penulis merupakan anak ke delapan dari delapan bersaudara.

Pada tahun 2008, penulis lulus dari MA Negeri 4 Jakarta dan pada tahun yang sama penulis lulus seleksi masuk IPB melalui Undangan Seleksi Masuk IPB (O)SMI). Penulis masuk dalam program studi Biologi, Fakultas Matematika dan IImu Pengetahuan Alam.

जelama mengikuti kegiatan perkuliahan, penulis pernah menjadi asisten praktikum Biologi Dasar pada tahun ajaran 2012/2013. Selain menjadi asisten Praktikum, penulis juga sempat mengikuti kegiatan nonakademis seperti Kampoeng MIPA (Bina Desa) divisi Pengembangan Masyarakat pada tahun 2010/2011. Di samping itu, penulis juga mengikuti beberapa kegiatan kepanitiaan seperti Pesta Sains pada tahun 2010 yang tergabung dalam divisi Tim Khusus, dan Musyawarah Wilayah Ikatan Himpunan Mahasiswa Biologi Indonesia (TKAHIMBI) divisi konsumsi pada tahun 2011.

Penulis melaksanakan kegiatan Studi Lapang di Pangandaran dengan judul Pemasaran Kerajinan Produk Laut dan Eksplorasi Keragamannya di Taman Wisata Alam Pangandaran pada tahun 2010. Penulis juga melaksanakan Praktik Ëapangan di Perusahaan Ultrajaya Milk Industry, Tbk. di daerah Padalarang, Kabupaten Bandung pada tahun 2011 dengan judul Proses Pengolahan Air (Water Ereatment). 